\title{
Mammary Uptake, Portal-Drained Visceral Flux, and Hepatic Metabolism of Free and Peptide-Bound Amino Acids in Cows Fed Steam-Flaked or Dry-Rolled Sorghum Grain Diets
}

\author{
H. Tagari, ${ }^{\star 1}$ K. Webb Jr.,† B. Theurer, $\neq$ T. Huber, $\neq$ D. DeYoung,§ P. Cuneo,\| J. E. P. Santos, $\ddagger^{2}$ J. Simas, $\ddagger^{3}$ \\ M. Sadik, $\ddagger^{4}$ A. Alio, $\ddagger^{5}$ O. Lozano,$\ddagger^{6}$ A. Delgado-Elorduy, $\ddagger^{7}$ L. Nussio, $\ddagger^{8}$ C. M. M. Bittar,$\ddagger^{9}$ and F. Santos $\ddagger^{9}$ \\ *Department of Animal Sciences, Faculty of Agricultural, Food and Environmental Quality Sciences, The Hebrew University of Jerusalem, \\ Rehovot, Israel 76100 \\ †Department of Animal and Poultry Sciences, Virginia Polytechnic Institute and State University, Blacksburg 24061 \\ ‡Department of Animal Sciences, \\ §Department of Veterinary Sciences, and \\ ||University Animal Care, University of Arizona, Tucson 85721
}

\begin{abstract}
Our objectives were to measure net fluxes of free AA (FAA) and peptide-bound AA (PBAA) across portaldrained viscera, liver, splanchnic tissues, and mammary tissues, and milk AA output of lactating Holstein cows ( $\mathrm{n}=8,86 \pm 8 \mathrm{~d}$ in milk). Cows were fed an alfalfabased total mixed ration containing $40 \%$ steam-flaked (SFS) or dry-rolled (DRS) sorghum grain. The total mixed rations were offered at 12 -h intervals in a crossover design. Blood samples were obtained from indwelling catheters in portal, hepatic, and mammary veins and from mesenteric or costoabdominal arteries every $2 \mathrm{~h}$ from each cow and diet. Intake of dry matter was 17.9 and $18.6 \mathrm{~kg} / \mathrm{d}$ of the SFS and DRS diets, respectively, but dropped to $16.3 \mathrm{~kg} / \mathrm{d}$ for cows fed the SFS diet in the last 3 experimental days, sampling day included. Milk and milk crude protein yields (kg/12-h sampling) were 13.85 vs. 13.25 and 0.425 vs. 0.396 for cows fed SFS or DRS, respectively, and were not affected by the
\end{abstract}

Received August 22, 2007.

Accepted September 26, 2007.

${ }^{1}$ Corresponding author: tagari@agri.huji.ac.il

${ }^{2}$ Present address: Veterinary Training and Research Center, University of California-Davis, Tulare, CA 93274.

${ }^{3}$ Present address: Potzleinsdorferstrasse 168c, 1180 Vienna, Austria.

${ }^{4}$ Present address: Faculty of Agriculture, University of Guyana, Turkeyen, Greater Georgetown, Guyana.

${ }^{5}$ Present address: c/o Dr. L. M. Moussa, B.P. 527, Niamey, Niger, West Africa.

${ }^{6}$ Present address: Universidad Autonoma de Sinaloa, Escuela de Medicina Veterinariay Zootecnia, Apartado 1057, Culiacan, Sinaloa, CP 80000, Mexico.

${ }^{7}$ Present address: Paseo del Venado \#217, Fracc. Los Vinedos. Torreon, Coahuila CP 27019, Mexico.

${ }^{8}$ Present address: Departamento de Zootecnia, Escola Superior de Agricultura, Luiz de Queiroz, Universidade de São Paulo, Piracicaba, São Paulo 12.400, Brazil.

${ }^{9}$ Present address: Dept. Zootecnia/ESALQ, Univ. São Paulo, Piracicaba, SP, Brazil. considerable drop in dry matter intake of cows fed the SFS diet during the last 3 experimental days. The portal-drained visceral flux of total essential FAA was 417 and $442 \mathrm{~g} / 12 \mathrm{~h}$ (SEM 63) in cows fed SFS and DRS, respectively. However, the portal-drained visceral flux of 7 essential PBAA out of the 9 determined was numerically greater in cows fed the SFS diet, and total essential PBAA in that treatment was $77.4 \pm 22.2$ compared with $35.4 \pm 50.2 \mathrm{~g} / 12 \mathrm{~h}$ for cows fed the DRS diet. This phenomenon was again observed in a greater total splanchnic flux (FAA + PBAA) of 462 and $371 \mathrm{~g} / 12$ $\mathrm{h}$ in SFS- and DRS-fed cows, respectively. Mammary uptake of essential AA from both pools (free and peptide bound), and recovery of essential AA in milk, was again numerically higher in SFS-fed cows. In addition to FAA, quantifying the contribution of PBAA may improve our understanding of tissue use of AA substrates, and this may ultimately lead to improved diet formulations with respect to intestinal absorption and mammary uptake of AA.

Key words: amino acid, peptide, dairy cow, flaked sorghum

\section{INTRODUCTION}

The processing of cereal grain prior to its feeding to cattle is essential for the prevention of digestive disorders, but it also improves its utilization, and hence animal performance (Theurer et al., 1999). Processing involves either physically breaking the grain by grinding or dry rolling, or treating with steam and then rolling or flaking, and even extruding. Earlier studies have shown that the improvement in grain utilization is due mainly to an increase in its starch digestibility (Theurer et al., 1999). Treating the grain with steam prior to its physical treatment further improves its ruminal fermentability and digestion, making this the 
most effective treatment of sorghum grain (Theurer et al., 1999).

An increase in available energy supply to ruminal microorganisms enhances microbial protein synthesis (Bauchop and Elsden, 1969). Later studies showed that the improved starch digestion is partially achieved via its increased degradation in the rumen (Oliveira et al., 1995). This is due to more extensive starch fermentation by ruminal microbial activity, accompanied by enhanced microbial protein synthesis (Sniffen and Robinson, 1987). The AA profiles of microbial proteins differ considerably from those of dietary origin (Czerkawski, 1976), and the aforementioned changes in rumen fermentation and digestion may therefore alter the proportions of RDP to RUP leaving the rumen. The source of protein may also alter the profile of the AA flowing into the gut (Tagari et al., 1995), or the composition of the intestinal degraded-protein fractions (i.e., degraded to peptides comprising varying numbers of AA), which are subject to absorption from the gastrointestinal tract (GIT).

In a previous study (Tagari et al., 2004), we reported that considerable amounts of peptide-bound (PB) AA were found in the portal-drained visceral flux (PDVF) of lactating cows fed steam-flaked or steam-rolled corn grain to densities of 360 or $490 \mathrm{~g} / \mathrm{L}$, respectively. Further, PDVF of PB-Gly, PB-His, and PB-Ser were greater in cows fed steam-flaked corn, whereas that of PB-Asp was greater in cows fed steam-rolled corn. Moreover, mammary uptake (MU) of PBAA in both treatments varied from modest (Ile, Leu) to substantial amounts (Lys, Met, Ser, and Thr) and was significantly higher, or tended toward significance, in cows fed steam-flaked corn, with the exception of PB-Ser, the MU of which was higher in cows fed steam-rolled corn.

Indeed, some controversy exists regarding the role or share of PBAA in the various fluxes between the body compartments or in MU. The controversy relates mainly to the accuracy of the analytical methods used and the significance of the contribution (i.e., importance), as detailed in our previous paper (Tagari et al., 2004). However, several reports have indicated considerable involvement of the PBAA fraction in PDVF, MU, liver flux, or splanchnic fluxes (Koeln et al., 1993; Seal and Parker, 1996; Remond et al., 2000; Tagari et al., 2004).

The current study was conducted with lactating dairy cows fed regular dairy diets containing either dry-rolled or steam-flaked sorghum grain (DRS and SFS, respectively). The objectives were to quantify the effects of processing the sorghum grain on the cows' portaldrained visceral (PDV), splanchnic, hepatic, and mammary fluxes of free AA (FAA) and PBAA in relation to milk and milk protein yields and composition. In addition, MU from plasma FAA and PBAA pools was compared with milk CP and AA output.

\section{MATERIALS AND METHODS}

\section{Cows and Diets}

Animal care and housing, surgical preparation of cows, the steam-flaking process, sampling routine, and analytical protocols were previously described in greater detail (Delgado-Elorduy et al., 2002a). Briefly, 8 Holstein cows in early lactation ( $86 \pm 8$ DIM, 6 first lactation, 2 second lactation) were randomly assigned to 2 dietary treatments (SFS or DRS) in a crossover design. Fluxes of FAA and PBAA were determined across PDV, liver, splanchnic (PDV + liver), and mammary tissues, as was their effect on milk yield and milk protein output. Cows were fed TMR to meet NRC (1989) requirements for $\mathrm{NE}_{\mathrm{L}}, \mathrm{CP}, \mathrm{NDF}, \mathrm{Ca}$, and $\mathrm{P}$. The diets differed only in the method of processing the sorghum grain: DRS grains were moderately ground to a density of $643 \mathrm{~g} / \mathrm{L}$, and SFS grains were moderately ground to a density of $360 \mathrm{~g} / \mathrm{L}$. The TMR contained $39 \%$ alfalfa hay and $40 \%$ sorghum grain (Table 1) and was offered at $10 \%$ in excess of appetite for ad libitum consumption.

Cows were housed in partially shaded, individual pens equipped with continuously engaged fans. Diets were offered at 0600 and $1800 \mathrm{~h}$ daily, right after milking. Cows were adapted to the diets for an average of $13 \mathrm{~d}$ (range $=12$ to $16 \mathrm{~d}$ ) before blood and milk sampling and then switched to the other diet after feed, milk, and blood sampling were completed.

\section{Surgery, Blood Collection, and Blood Flow Measurements}

Surgery, blood collection, and blood flow measurements were as described previously (Delgado-Elorduy et al., 2002a). Surgical procedures and care of cows were approved by the University of Arizona Institutional Animal Care and Use Committee (approval no. 94-12887). Lactating cows were surgically implanted ( $22 \pm 3$ DIM) with indwelling catheters in the mesenteric, portal, and hepatic veins and the mesenteric artery. Procedures for catheter implantation and maintenance of patency were as described by Huntington et al. (1989), except for catheterization of the hepatic vein, which was performed with the assistance of a linear ultrasound scanner equipped with a $5.0-\mathrm{MHz}$ probe (Aloka-500V, Corometrics Medical Systems Inc., New Haven, CT) to locate the vein and to confirm placement of the catheter. Temporary catheters for sampling blood from the mammary vein were implanted 1 to $2 \mathrm{~d}$ before sampling in the s.c. abdominal (mammary) vein, and the tip was guided backward by palpation and placed as close as 
Table 1. Ingredients and chemical analyses of experimental TMR with processed sorghum grain

\begin{tabular}{|c|c|c|c|}
\hline Item & Percentage of TMR & & \\
\hline \multicolumn{4}{|l|}{ Ingredient } \\
\hline Alfalfa hay & 39.0 & & \\
\hline Sorghum grain ${ }^{1}$ & 40.0 & & \\
\hline Whole cottonseed & 11.0 & & \\
\hline Soybean meal & 7.0 & & \\
\hline Cottonseed hulls & 3.0 & & \\
\hline Mineral and vitamin $\operatorname{mix}^{2}$ & 3.0 & & \\
\hline Chemical analyses (DM basis) & Steam-flaked & Dry-rolled & SEM \\
\hline DM & 86.0 & 88.1 & 0.39 \\
\hline Starch & 29.6 & 30.0 & 0.09 \\
\hline $\mathrm{CP}^{3}$ & 17.7 & 17.9 & 0.43 \\
\hline $\mathrm{N}$ & 2.84 & 2.86 & 0.02 \\
\hline $\mathrm{NDF}$ & 28.1 & 28.4 & 0.16 \\
\hline $\mathrm{ADF}$ & 18.1 & 17.7 & 0.04 \\
\hline $\mathrm{NE}_{\mathrm{L}},{ }^{4} \mathrm{Mcal} / \mathrm{kg}$ of $\mathrm{DM}$ & 1.79 & 1.64 & - \\
\hline \multicolumn{4}{|c|}{${ }^{1}$ Density: dry-rolled = $643 \mathrm{~g} / \mathrm{L} ;$ steam-flaked = $360 \mathrm{~g} / \mathrm{L}$} \\
\hline \multirow{2}{*}{\multicolumn{4}{|c|}{ 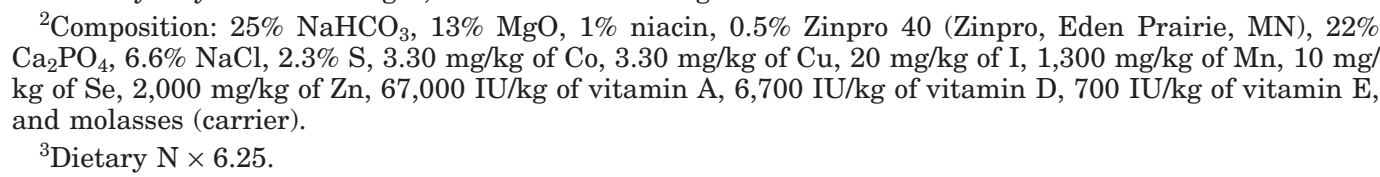 }} \\
\hline & & & \\
\hline \multicolumn{4}{|c|}{$\begin{array}{l}{ }^{4} \text { Estimated from Theurer et al. (1999) for steam-flaked sorghum grain }(2.20 \text { and } 1.84 \mathrm{Mcal} / \mathrm{kg} \text { of DM for } \\
\text { SFS and DRS, respectively) and from NRC (1989) guidelines for the other feeds. }\end{array}$} \\
\hline
\end{tabular}

possible to the udder ( 2 to $5 \mathrm{~cm}$ ). Two cows lost patency of hepatic catheters. In addition, 2 cows lost patency of mesenteric artery catheters, and these were replaced by inserting a catheter into a costoabdominal artery as described by Haibel et al. (1989). During sampling, cows were infused via the mesenteric vein catheter with a sterile aqueous solution ( $\mathrm{pH}$ 7.4) of paraaminohippuric acid (PAH), which began prior to blood collection. Blood samples were drawn simultaneously from the artery, portal, hepatic, and mammary veins into heparinized syringes 5 to 7 min before completion of the PAH infusion. Syringes containing the samples were immediately immersed in an ice slurry $\left(0\right.$ to $\left.1^{\circ} \mathrm{C}\right)$. Plasma was then harvested and a methanol filtrate was prepared (Delgado-Elorduy et al., 2002a). Six sets of each of the 4 samples were collected at 2 -h intervals after animals had consumed their respective diet for an average of $11 \mathrm{~d}$ (range $=7$ to $14 \mathrm{~d}$ ).

\section{Feed and Milk Collection and Analysis}

Feed and ort samples were obtained for 5 to $7 \mathrm{~d}$ immediately prior to and on the day of sampling and were pooled for each cow and diet. Milk production was recorded daily and milk samples were collected twice daily for $4 \mathrm{~d}$ before and on the day of blood sampling. To enable us to study the relationship between net PDV appearance and MU of FAA and PBAA as compared with AA secretion in milk, an extra milk sample was collected from the p.m. milking on the day of sampling.
Diets and orts were analyzed for DM, CP, total starch, NDF, and ADF. Daily milk samples were analyzed for protein by using infrared procedures. Analytical protocols for all of these analyses were as described previously (Delgado-Elorduy et al., 2002a).

\section{FAA and PBAA Determination in Plasma and $A A$ in Milk}

The AA composition of milk proteins and the composition of FAA and PBAA in the plasma were determined by previously described protocols (Delgado-Elorduy et al., 2002a). Briefly, methanol supernatants of plasma were filtered through passivated Amicon Centricon YM3 filter devices (Millipore Corporation, Bedford, MA) with a molecular weight cutoff of 3,000. Filtrates were collected into microcentrifuge tubes (Fisher Scientific, Pittsburgh, PA), purged with $\mathrm{N}_{2}$, and stored refrigerated $\left(2^{\circ} \mathrm{C}\right)$ until analysis. Filtered samples were analyzed for FAA and PBAA by HPLC using the Waters Pico.Tag method (Bidlingmeyer et al., 1984). Samples of plasma filtrate for PBAA analysis or samples of skim milk for analysis of AA composition were hydrolyzed in $\mathrm{HCl}$ vapor at $112^{\circ} \mathrm{C}$ for $24 \mathrm{~h}$ prior to analysis. The $\mathrm{HCl}$ (constant boiling, Pierce, Rockford, IL) contained sodium sulfite $(0.1 \%, \mathrm{wt} / \mathrm{vol})$ and phenol $(1.1 \mathrm{mg} / \mathrm{mL})$. Replicate analyses for FAA and PBAA from a particular sample were performed consecutively. The AA content of hydrolyzed samples was corrected for losses occurring during hydrolysis (Delgado-Elorduy et al., 
2002a). The PBAA content of samples was calculated as the difference between the corrected AA content of the hydrolyzed filtrates and their FAA content. Recoveries for PB-Tyr following hydrolysis were very poor; hence, data for this PBAA are not presented.

\section{Calculations of Blood Flow}

Blood flow in the portal and hepatic veins was calculated by downstream dilution of PAH as described by Katz and Bergman (1969), as follows:

$$
\mathrm{BF}=\left(\mathrm{PAH}_{\mathrm{IR}} \div \mathrm{PAH}_{[\mathrm{V}-\mathrm{A}]}\right),
$$

where BF denotes blood flow (L/h), PAHIR is the infusion rate of $\mathrm{PAH}(15,000 \mathrm{mg} / \mathrm{h})$, and $\mathrm{PAH}_{[\mathrm{V}-\mathrm{A}]}$ is the venoarterial concentration differences in PAH $(\mathrm{mg} / \mathrm{L})$. Hepatic artery blood flow was calculated as the difference between hepatic and portal vein flows. Mammary blood flow was determined and calculated by Fick's principle as described previously (Delgado-Elorduy et al., 2002a). Calculations were corrected for plasma embedded in the packed-cell portion of the hematocrit according to Elwyn et al. (1972), and blood flow was calculated by dividing the plasma flow by 0.7728 (proportion of corrected plasma in blood).

\section{Calculation of Net Fluxes of FAA and PBAA}

Calculations of net fluxes of nitrogen components across PDV, liver, and splanchnic tissues were as follows:

$$
\begin{gathered}
\mathrm{NFPDV}=\mathrm{PDVF}=\mathrm{PPF} \times \mathrm{N}_{[\mathrm{P}-\mathrm{A}]}, \\
\mathrm{NF}_{\text {Liver }}= \\
\text { liver uptake }=\left(\mathrm{HAPF} \times \mathrm{N}_{[\mathrm{H}-\mathrm{A}]}\right) \\
+\left(\mathrm{PPF} \times \mathrm{N}_{[\mathrm{H}-\mathrm{P}]}\right), \text { and } \\
\mathrm{NF}_{\text {Splanchnic }}= \\
\text { splanchnic flux }(\mathrm{SF})=\mathrm{HPF} \times \mathrm{N}_{[\mathrm{H}-\mathrm{A}]},
\end{gathered}
$$

where NFPDV, $\mathrm{NF}_{\text {Liver }}$, and $\mathrm{NF}_{\text {Splanchnic }}$ are net fluxes (g/ $12 \mathrm{~h}$ ) of PDV, liver, and splanchnic tissues, respectively; $\mathrm{PPF}, \mathrm{HAPF}$, and HPF are portal vein, hepatic artery, and hepatic vein plasma flows, respectively; and $\mathrm{N}_{[\mathrm{P}-\mathrm{A}]}$, $\mathrm{N}_{[\mathrm{H}-\mathrm{A}]}$, and $\mathrm{N}_{[\mathrm{H}-\mathrm{P}]}$ are portal-arterial, hepatic-arterial, and hepatic-portal differences $(\mathrm{mg} / \mathrm{L}$ ) for nitrogen (FAA or PBAA), respectively.

Mammary uptake or mammary flux $\left(\mathrm{NF}_{\mathrm{M}}\right)$ of FAA and PBAA and mammary extraction efficiency (MEE) were calculated according to Brockman and Bergman (1975) as

$$
\begin{gathered}
\mathrm{MU}=\mathrm{MPF} \times \mathrm{FAA}_{[\mathrm{M}-\mathrm{A}]} \text { or } \mathrm{PBAA}_{[\mathrm{M}-\mathrm{A}]}, \text { and } \\
\mathrm{MEE}=100 \times(\mathrm{A}-\mathrm{M}) \div \mathrm{A},
\end{gathered}
$$

where MU is the net mammary uptake (flux) of FAA or PBAA ( $\mathrm{g} / 12 \mathrm{~h}), \mathrm{MPF}$ is the mammary plasma flow, and $\mathrm{A}$ and $\mathrm{M}$ are concentrations of FAA or PBAA in the artery and mammary vein, respectively.

Concentrations of PB-Glu + Gln and PB-Asp + Asn were calculated by assuming that all free or PB-Gln and PB-Asn were converted quantitatively during hydrolysis to Glu and Asp and were determined as such; hence, the equation was as follows:

$$
\text { PB-Glu + PB-Gln = TH Glu }-(\text { Glu + Gln }),
$$

where TH-Glu is total Glu in the hydrolyzate, PB-Glu or PB-Gln is peptide-bound Glu or Gln, and Glu or Gln is free Glu or Gln.

\section{Statistical Analysis}

Plasma concentrations, nutrient fluxes, and lactational performance data were analyzed by ANOVA by using the previously outlined GLM procedure (DelgadoElorduy et al., 2002a). Significance of the difference from zero was examined by a one-sample $t$-test. The possibility of a carryover effect was tested by ANOVA, with treatment, treatment sequence, and cow nested within treatment sequence as main effects. Nonsignificance of the interaction between treatment and treatment sequence was used as a criterion for the absence of a carryover effect.

\section{RESULTS}

\section{Full-Period Animal Performance}

Performances for the whole experimental period are published elsewhere (Delgado-Elorduy et al., 2002a). Briefly, average DMI of cows fed the SFS diet was lower by approximately $4.4 \%$ than that of cows fed the DRS diet, although not significantly so (Table 2). However, daily intake of the SFS diet increased during the first few days of the experiment above that of the DRS diet, and then declined considerably to a level that was lower on the sampling day by approximately $10 \%$ than that of the DRS diet (Figure 1 and Table 2). Intake of other nutrients of cows fed the SFS diets, except $\mathrm{NE}_{\mathrm{L}}$, decreased to the same extent. It should be noted, however, that the rate of starch hydrolysis by amyloglucosidase was much higher in the SFS grain than in the DRS grain (65.6\% in SFS vs. 24.4\% in DRS; Delgado-Elorduy et al., 2002a). Concomitantly, the decrease in the intake of calculated energy in the SFS diet was considerably smaller than that observed for other nutrients because of its improved starch fermentation and digestibility. Animal performance under both treatments, with respect to nitrogenous components for the whole experi- 
Table 2. Intake and lactational performance of dairy cows fed diets containing steam-flaked (SFS) or dryrolled (DRS) sorghum grain

\begin{tabular}{lcccc}
\hline & \multicolumn{2}{c}{ Diet } & & \\
\cline { 2 - 3 } Item & SFS & DRS & SEM & $P<$ \\
\hline Cows, $\mathrm{n}$ & 8 & 8 & & \\
Intake, kg/d & & & & \\
DM (whole experiment) & 17.9 & 18.6 & 0.3 & 0.18 \\
DM (last 3 d) & 16.3 & 18.7 & 1.5 & 0.19 \\
CP & 3.2 & 3.3 & 0.1 & 0.16 \\
N & 0.506 & 0.528 & 0.01 & 0.12 \\
NE, Mcal/d (calculated) & 32.0 & 30.4 & 0.6 & 0.12 \\
Milk yield on sampling day & & & & \\
Total, kg/12 h & 13.85 & 13.25 & 0.56 & 0.44 \\
CP (DHI), kg/12 h & 0.425 & 0.396 & 0.20 & 0.44 \\
CP (DHI), \% & 3.1 & 3.0 & 0.3 & NS \\
Total AA, kg/12 h & 0.389 & 0.365 & 0.094 & 0.16 \\
Total essential AA (without Trp), kg/12 h & 0.190 & 0.175 & 0.080 & 0.24 \\
\hline
\end{tabular}

mental period or for the sampling day, did not differ despite the substantial decrease in DMI during the last 3 experimental days (Table 2 ).

\section{Concentrations of FAA and PBAA in Arterial, Portal, Hepatic, and Mammary Veins}

Arterial concentrations of FAA tended to be lower in cows fed the SFS diet vs. the DRS diet, and significantly $(P<0.05$ to 0.1$)$ so for the essential AA (EAA) Ile, Leu, and Thr, whereas the trend was nonsignificant for Val (Table 3). In the PBAA pool, Arg and Lys concentrations were lower $(P<0.05)$ in SFS cows, whereas those of Phe and Val tended to be so. Concentrations of total free EAA were lower in SFS cows by approximately $11 \%(P<0.078)$. Although the concentrations of most of the PBAA in SFS-fed cows were lower than those in DRS-fed cows, only concentrations of Arg, Lys, and total PB-EAA (which were lower by approximately 40\%)

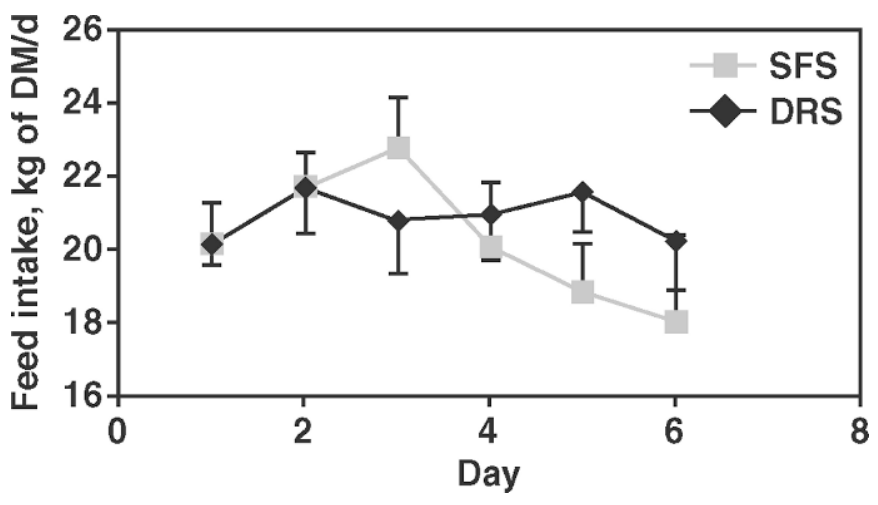

Figure 1. Feed intake of cows fed dry-rolled (DRS) or steam-flaked (SFS) sorghum grain. Values are means $\pm \mathrm{SE}$ and $\mathrm{n}=8$. were significantly so $(P<0.05,0.01$, and 0.07 , respectively).

A similar pattern with respect to the differences in FAA and PBAA appeared in the portal vein (Table 4). Likewise, in the artery the lower concentrations of the FAA Ile, Leu, and Thr were sustained $(P<0.07,0.07$, and 0.05) in cows fed the SFS diets, and the same was true for total free EAA, nonessential (NE) AA and total FAA $(P<0.08,0.06$, and 0.05$)$. In the PBAA pool, concentrations of PB-Val were higher $(P<0.08)$ in cows fed the SFS diet, but those of PB-Met were higher in DRS-fed cows, and concentrations of PB-Arg and PBLys tended to be so $(P<0.11)$.

The concentrations of most of the free EAA in the hepatic vein of cows fed the DRS ration were also higher $(P<0.05$ to 0.1$)$, or tended $(P<0.11$ to 0.2$)$ to be so, than when the cows were fed the SFS ration, and all of the totals were higher $(P<0.05$ to 0.1$)$ as well (Table $5)$. In the PBAA pool, however, the concentrations of most of the essential PBAA in cows fed the SFS diets were numerically higher or similar to those in cows fed the DRS diet. It is noteworthy that total essential PBAA in SFS-fed cows differed from zero $(P<0.012)$, whereas in DRS-fed cows, it did not.

The concentrations in the mammary vein of most free EAA were lower in SFS-fed cows, but only those of Thr and Leu were significantly $(P<0.05$ to 0.1$)$ so, and those of Ile tended to be so (Table 6). However, the concentrations of all the 3 totals of the free AA were significantly lower in cows fed the SFS diet. In the PBAA pool, the concentrations of total PBAA were lower $(P<0.001$ to 0.1$)$ or tended $(P<0.11$ to 0.2$)$ to be so when the cows were fed the SFS diet.

\section{Fluxes of FAA and PBAA Between Plasma Pools}

$\boldsymbol{P D V F}$. With the exception of His, Trp, and Val, PDVF of the 7 other free EAA were higher when the cows 
TAGARI ET AL.

Table 3. Arterial concentrations (mg/L of plasma) of free (F) and peptide-bound (PB) AA in plasma of cows fed steam-flaked (SFS) or dry-rolled (DRS) sorghum grain diets $(\mathrm{n}=8)$

\begin{tabular}{|c|c|c|c|c|c|c|c|c|c|c|c|c|}
\hline \multirow[b]{3}{*}{$\mathrm{AA}^{1}$} & \multirow{2}{*}{\multicolumn{4}{|c|}{ FAA }} & \multicolumn{6}{|c|}{ PBAA } & \multirow[b]{3}{*}{$\mathrm{SEM}^{3}$} & \multirow[b]{3}{*}{$P<<^{4}$} \\
\hline & & & & & \multicolumn{3}{|c|}{ SFS } & \multicolumn{3}{|c|}{ DRS } & & \\
\hline & $\begin{array}{l}\text { SFS, } \\
\text { mean }^{2}\end{array}$ & $\begin{array}{c}\text { DRS, } \\
\text { mean }^{2}\end{array}$ & $\mathrm{SEM}^{3}$ & $P<4$ & Mean & $\mathrm{SEM}^{5}$ & $P<^{6}$ & Mean & $\mathrm{SEM}^{5}$ & $P<^{6}$ & & \\
\hline Ala & 18.7 & 19.5 & 0.7 & & 2.7 & 0.6 & $*$ & 3.1 & 0.6 & $*$ & 0.4 & \\
\hline Arg & 9.8 & 10.8 & 0.4 & & 0.5 & 0.1 & * & 1.1 & 0.2 & * & 0.2 & $*$ \\
\hline Asn & 3.6 & 2.6 & 0.5 & & & & & & & & & \\
\hline Asp & 2.9 & 3.8 & 0.4 & \# & 3.2 & 0.3 & $*$ & 2.4 & 0.5 & * & 0.5 & \\
\hline Cit & 13.7 & 16.6 & 0.8 & * & & & & & & & & \\
\hline Gln & 13.7 & 16.2 & 0.9 & $\wedge$ & & & & & & & & \\
\hline Glu & 7.1 & 7.5 & 0.3 & & 8.5 & 1.6 & $*$ & 8.8 & 1.9 & $*$ & 1.4 & \\
\hline Gly & 17.3 & 17.6 & 1.1 & & 26.2 & 2.2 & $*$ & 27.2 & 1.4 & * & 0.8 & \\
\hline His & 5.5 & 5.4 & 0.4 & & 2.7 & 0.6 & $*$ & 3.6 & 0.4 & $*$ & 0.5 & \\
\hline Нур & 1.8 & 1.9 & 0.1 & & 1.1 & 0.1 & $*$ & 1.1 & 0.1 & $*$ & 0.1 & \\
\hline Ile & 14.9 & 17.3 & 0.8 & $\wedge$ & 0.1 & 0.2 & & 0.3 & 0.2 & & 0.3 & \\
\hline Leu & 21.8 & 25.7 & 1.2 & $\wedge$ & 1.6 & 0.1 & $*$ & 1.9 & 0.3 & * & 0.2 & \\
\hline Lys & 7.1 & 7.6 & 0.4 & & 2.1 & 0.3 & $*$ & 3.0 & 0.4 & * & 0.2 & $*$ \\
\hline Met & 2.8 & 2.9 & 0.2 & & 1.3 & 0.3 & $*$ & 1.6 & 0.1 & $*$ & 0.2 & \\
\hline Orn & 3.2 & 3.7 & 0.2 & $\wedge$ & 2.3 & 0.3 & $*$ & 2.9 & 0.4 & * & 0.2 & $*$ \\
\hline Phe & 9.0 & 9.2 & 0.4 & & 0.1 & 0.1 & & 0.6 & 0.3 & & 0.2 & \# \\
\hline Pro & 9.2 & 10.1 & 0.6 & & 1.6 & 0.2 & $*$ & 1.6 & 0.2 & * & 0.1 & \\
\hline Ser & 7.2 & 7.2 & 0.4 & & 2.6 & 0.3 & $*$ & 2.8 & 0.3 & * & 0.3 & \\
\hline Thr & 8.3 & 9.5 & 0.3 & $*$ & 1.0 & 0.2 & $*$ & 1.3 & 0.2 & * & 0.1 & \# \\
\hline Trp & 6.8 & 7.0 & 0.2 & & & & & & & & & \\
\hline Tyr & 9.7 & 10.8 & 0.4 & & & & & & & & & \\
\hline Val & 29.1 & 32.7 & 1.4 & \# & 0.9 & 0.2 & $*$ & 1.1 & 0.2 & $*$ & 0.2 & \\
\hline TEAA & 115.2 & 127.9 & 4.2 & $\wedge$ & 10.4 & 1.2 & $*$ & 14.7 & 1.7 & $*$ & 1.4 & $\wedge$ \\
\hline TNEAA & 108.0 & 117.5 & 4.3 & \# & 48.2 & 5.1 & $*$ & 49.8 & 2.7 & $*$ & 4.1 & \\
\hline TAA & 223.4 & 245.4 & 7.9 & & 58.6 & 6.3 & $*$ & 64.5 & 3.9 & * & 4.9 & \\
\hline
\end{tabular}

${ }^{1} \mathrm{Cit}=$ citrulline Hyp = hydroxyproline Orn = ornithine $; \mathrm{TEAA}=$ total essential AA; $\mathrm{TNEAA}=$ total nonessential AA; TAA = total AA (TAA).

${ }^{2}$ All FAA concentrations differ $(P<0.05)$ from zero.

${ }^{3}$ Standard error of the model least squares means.

${ }^{4}$ Significance of difference between treatments within pools, at levels $* P<0.001$ to $0.05, \wedge P<0.05$ to 0.1 , or ${ }^{\#} P<0.11$ to 0.2 (trend), respectively.

${ }^{5}$ Standard error of the mean.

${ }^{6}$ Significance of difference from zero, at levels $* P<0.001$ to $0.05,{ }^{\wedge} P<0.05$ to 0.1 , or ${ }^{\#} P<0.11$ to 0.2 (trend), respectively.

were fed the DRS diets, and the same held true for most of the free NEAA (Table 7). However, none of these differences was significant. The PDVF of the EAA His and Lys differed from zero in both treatments $(P<0.01)$, whereas Arg and Leu differed from zero $(P<0.05)$ only in cows fed the SFS diet, and Ile and Val tended toward differing significantly. Total PDVF of PB-EAA in SFSfed cows was twice as high as in DRS-fed cows; the former differed from zero $(P<0.05)$, whereas the latter did not. Adding the PDVF of the FAA and PBAA pools reduced or nullified the apparent differences between the PDVF of both treatments; hence, PDVF of most essential PBAA became similar or nearly similar for both treatments. For the NEAA in the PDVF that differed from zero in both treatments $(P<0.01$ to 0.1$)$, noteworthy differences were the very high quantities of PB-Gly, the high quantities of PB-Asp, and the smaller quantities of PB-ornithine. The PDVF of the NEAA,
PB-Ala and PB-Ser, differed from zero $(P<0.05)$ only in cows fed the SFS diets.

Considerable negative PDVF of PB-Glu was recorded, which differed from zero $(P<0.05)$ and tended to be higher $(P<0.11)$ in SFS-fed cows. This phenomenon was also observed when cows were fed steam-flaked or rolled corn grain (Tagari et al., 2004) and is discussed further on.

Liver Flux (Liver Flux = Liver Uptake). Liver flux (Table 8) of approximately half of the FAA in cows fed the SFS diets differed from zero $(P<0.05$ to 0.1$)$, as compared with a smaller number in cows fed the DRS diets. Liver flux of total free EAA differed from zero $(P$ $<0.05)$ only in cows fed the SFS diets, whereas liver flux of total FAA differed from zero $(P<0.05)$ in cows fed both diets.

Furthermore, no differences between treatments, except for Glu $(P<0.05)$ and trends for Ala and His, were 
Table 4. Portal concentrations (mg/L plasma) of free (F) and peptide-bound (PB) AA in plasma of cows fed steam-flaked (SFS) or dry-rolled (DRS) sorghum grain diets $(\mathrm{n}=8)$

\begin{tabular}{|c|c|c|c|c|c|c|c|c|c|c|c|c|}
\hline \multirow[b]{3}{*}{$\mathrm{AA}^{1}$} & \multirow{2}{*}{\multicolumn{4}{|c|}{ FAA }} & \multicolumn{6}{|c|}{ PBAA } & \multirow[b]{3}{*}{$\mathrm{SEM}^{3}$} & \multirow[b]{3}{*}{$P<<^{4}$} \\
\hline & & & & & \multicolumn{3}{|c|}{ SFS } & \multicolumn{3}{|c|}{ DRS } & & \\
\hline & $\begin{array}{l}\text { SFS, } \\
\text { mean }^{2}\end{array}$ & $\begin{array}{l}\text { DRS, } \\
\text { mean }^{2}\end{array}$ & $\mathrm{SEM}^{3}$ & $P<^{4}$ & Mean & SEM $^{5}$ & $P<{ }^{6}$ & Mean & $\mathrm{SEM}^{5}$ & $P<^{6}$ & & \\
\hline Ala & 23.1 & 25.1 & 0.6 & $\wedge$ & 3.8 & 0.45 & * & 2.7 & 0.77 & * & 0.6 & \\
\hline Arg & 12.4 & 13.5 & 0.4 & \# & 0.9 & 0.12 & * & 1.4 & 0.23 & $*$ & 0.2 & \# \\
\hline Asn & 5.4 & 4.4 & 1.0 & & & & & & & & & \\
\hline Asp & 3.6 & 4.7 & 0.6 & & 4.5 & 0.23 & * & 4.1 & 0.86 & $*$ & 0.63 & \\
\hline Cit & 15.3 & 17.6 & 0.7 & $\wedge$ & & & & & & & & \\
\hline Gln & 16.0 & 17.8 & 0.8 & \# & & & & & & & & \\
\hline Glu & 8.3 & 9.1 & 0.3 & $\wedge$ & 5.6 & 0.97 & $*$ & 7.1 & 1.98 & $*$ & 0.14 & \\
\hline Gly & 19.2 & 19.4 & 0.9 & & 32.3 & 2.43 & $*$ & 36.4 & 1.94 & $*$ & 0.11 & $*$ \\
\hline His & 6.6 & 6.2 & 0.4 & & 3.4 & 0.52 & * & 4.2 & 0.47 & $*$ & 0.39 & \\
\hline Нур & 2.0 & 2.1 & 0.1 & & 1.1 & 0.1 & * & 1.0 & 0.12 & * & 0.08 & \\
\hline Ile & 18.0 & 20.4 & 0.7 & $\wedge$ & 0.9 & 0.54 & $\wedge$ & 0.3 & 0.18 & & 0.37 & \\
\hline Leu & 26.9 & 31.0 & 1.3 & $\wedge$ & 2.2 & 0.28 & * & 2.3 & 0.28 & * & 0.25 & \\
\hline Lys & 9.4 & 10.1 & 0.3 & \# & 3.1 & 0.4 & * & 3.8 & 0.39 & $*$ & 0.25 & \# \\
\hline Met & 4.0 & 4.3 & 0.2 & & 1.5 & 0.25 & * & 2.0 & 0.25 & $*$ & 0.14 & $\wedge$ \\
\hline Orn & 3.8 & 4.2 & 0.2 & \# & 2.7 & 0.29 & * & 3.3 & 0.41 & $*$ & 0.18 & $\wedge$ \\
\hline Phe & 12.1 & 12.5 & 0.4 & & 0.1 & 0.12 & \# & 0.8 & 0.62 & & 0.44 & \\
\hline Pro & 11.2 & 12.6 & 0.4 & $\wedge$ & 2.0 & 0.25 & * & 1.6 & 0.22 & * & 0.23 & \\
\hline Ser & 9.2 & 9.7 & 0.4 & & 3.4 & 0.37 & $*$ & 3.7 & 0.41 & $*$ & 0.34 & \\
\hline Thr & 10.2 & 11.6 & 0.2 & $*$ & 1.7 & 0.28 & $*$ & 1.6 & 0.42 & $*$ & 0.35 & \\
\hline Trp & 7.8 & 7.8 & 0.3 & & & & & & & & & \\
\hline Tyr & 12.8 & 13.8 & 0.5 & \# & & & & & & & & \\
\hline Val & 33.3 & 36.1 & 0.2 & $*$ & 1.5 & 0.26 & $*$ & 0.9 & 0.31 & $*$ & 0.19 & $\wedge$ \\
\hline TEAA & 140.6 & 153.5 & 4.3 & $\wedge$ & 15.2 & 2.01 & $*$ & 17.2 & 2.21 & \# & 9.9 & \\
\hline TNEAA & 129.7 & 140.5 & 3.4 & $\wedge$ & 55.3 & 5.03 & $*$ & 46.5 & 4.89 & * & 7.2 & \\
\hline TAA & 270.4 & 294.0 & 7.0 & $*$ & 70.5 & 6.77 & $*$ & 77.1 & 6.58 & $*$ & 16.8 & \\
\hline
\end{tabular}

${ }^{1}$ Cit $=$ citrulline; Hyp = hydroxyproline; Orn = ornithine; TEAA = total essential AA; TNEAA = total nonessential AA; TAA = total AA.

${ }^{2}$ All FAA concentrations differ $(P<0.05)$ from zero. Differs from zero at $* P<0.001$ to $0.05, \wedge P<0.05$ to 0.1 , or ${ }^{\#} P<0.11$ to 0.2 (trend), respectively.

${ }^{3}$ Standard error of the model least squares means.

${ }^{4}$ Significance of difference between treatments within pools, at levels $* P<0.001$ to $0.05, \wedge P<0.05$ to 0.1 , or ${ }^{\#} P<0.11$ to 0.2 (trend), respectively.

${ }^{5}$ Standard error of the mean.

${ }^{6}$ Significance of difference from zero, at levels ${ }^{*} P<0.001$ to $0.05,{ }^{\wedge} P<0.05$ to 0.1 , or ${ }^{\#} P<0.11$ to 0.2 (trend), respectively.

recorded. The liver of cows fed the SFS diets delivered Glu and Lys, as compared with liver uptake in cows fed the DRS diets, although liver uptake of only Glu differed from zero and differed between diets $(P<0.04)$. It is worth noting, however, that there was a tendency for the liver flux (liver uptake) of the free EAA Val, Thr, Met, Ile, His, and Arg and total free EAA to be greater in SFS-fed cows.

With respect to PBAA, an inverted trend, that is, less liver uptake or more delivery of PBAA by cows fed the SFS diets, was recorded for many AA, although the difference was significant for only PB-His, PB-Pro, PBSer $(P<0.05$ to 0.1$)$, and total PB-EAA $(P<0.05)$, relative to cows fed the DRS diets (Table 8). Liver fluxes (uptakes) in DRS-fed cows of total PBAA differed significantly from zero $(P<0.05)$, and those of PB-EAA and PB-NEAA tended to do so. As in the DRS-fed cows, liver flux of total PB-NEAA in SFS-fed cows was also negative. However, liver flux of total PB-EAA in cows fed the SFS diets was opposite that observed in DRSfed cows; that is, delivery into the hepatic vein took place and, although not differing from zero, it differed $(P<0.05)$ from the liver flux observed in DRS-fed cows. The total positive liver flux (delivery) of PB-EAA in SFS-fed cows was $40.1 \mathrm{~g} / 12 \mathrm{~h}$, whereas that of DRS-fed cows was $5.4 \mathrm{~g} / 12 \mathrm{~h}$, and was recorded for PB-Phe only.

Splanchnic Flux. Splanchnic fluxes (Table 9) of all FAA totals included, in cows fed both diets, differed from zero $(P<0.001$ to 0.05$)$. Splanchnic fluxes of most FAA were numerically lower in cows fed the SFS diets. However, splanchnic fluxes of individual PB-EAA were, in all cases, numerically larger in cows fed the SFS diets. Splanchnic flux of total PB-EAA in cows fed the SFS diets tended to be larger $(P<0.11)$ than in cows fed the DRS diets, thus making the combined (free + PB) splanchnic flux of total EAA similar for both diets. 
TAGARI ET AL.

Table 5. Hepatic concentrations (mg/L plasma) of free (F) and peptide-bound (PB) AA in plasma of cows fed steam-flaked (SFS) or dry-rolled (DRS) sorghum grain diets $(\mathrm{n}=5)$

\begin{tabular}{|c|c|c|c|c|c|c|c|c|c|c|c|c|}
\hline \multirow[b]{3}{*}{$\mathrm{AA}^{1}$} & \multirow{2}{*}{\multicolumn{4}{|c|}{ FAA }} & \multicolumn{6}{|c|}{ PBAA } & \multirow[b]{3}{*}{$\mathrm{SEM}^{3}$} & \multirow[b]{3}{*}{$P<{ }^{4}$} \\
\hline & & & & & \multicolumn{3}{|c|}{ SFS } & \multicolumn{3}{|c|}{ DRS } & & \\
\hline & $\begin{array}{l}\text { SFS, } \\
\text { mean }^{2}\end{array}$ & $\begin{array}{l}\text { DRS, } \\
\text { mean }^{2}\end{array}$ & $\mathrm{SEM}^{3}$ & $P<^{4}$ & Mean & $\mathrm{SEM}^{5}$ & $P<6$ & Mean & $\mathrm{SEM}^{5}$ & $P<^{6}$ & & \\
\hline Ala & 20.2 & 22.9 & 0.66 & $\wedge$ & 3.1 & 0.54 & $\wedge$ & 1.36 & 0.99 & & 1.1 & \\
\hline Arg & 11.8 & 13.7 & 0.44 & $\wedge$ & 0.8 & 0.26 & & 0.22 & 0.9 & & 0.73 & \\
\hline Asn & 3.3 & 5.6 & 0.79 & \# & & & & & & & & \\
\hline Asp & 4.1 & 3.5 & 0.66 & & 3.2 & 1.0 & $*$ & 4.3 & 0.44 & $*$ & 0.28 & \# \\
\hline Cit & 16.4 & 17.7 & 1.3 & & & & & & & & & \\
\hline Gln & 14.6 & 17.3 & 1.4 & \# & & & & & & & & \\
\hline Glu & 11.7 & 11.3 & 0.3 & & 2.3 & 1.41 & & 1.51 & 3.73 & & 1.8 & \\
\hline Gly & 16.7 & 18.8 & 1.9 & & 33.3 & 1.87 & $*$ & 33.2 & 1.95 & $*$ & 1.3 & \\
\hline His & 6.2 & 6.2 & 0.34 & & 4.1 & 0.25 & $*$ & 3.6 & 0.87 & $*$ & 0.88 & \\
\hline Нур & 1.8 & 1.9 & 0.16 & & 1.1 & 0.17 & * & 1.1 & 0.12 & $\wedge$ & 0.18 & \\
\hline Ile & 18 & 21.6 & 0.95 & $\wedge$ & 0.2 & 0.24 & \# & 1.3 & 0.98 & & 0.72 & \\
\hline Leu & 26.6 & 30.6 & 1.64 & \# & 1.9 & 0.33 & & 0.1 & 1.9 & & 1.49 & \\
\hline Lys & 9.1 & 10.3 & 0.42 & \# & 3 & 0.34 & * & 3.17 & 1.06 & * & 0.9 & \\
\hline Met & 3.6 & 4.2 & 0.14 & * & 1.3 & 0.19 & $\wedge$ & 0.6 & 0.77 & & 0.45 & \\
\hline Orn & 4.1 & 4.7 & 0.2 & $\wedge$ & 3 & 0.34 & $\wedge$ & 3.2 & 0.65 & $*$ & 0.06 & \\
\hline Phe & 10.6 & 11.3 & 0.33 & & 0.3 & 0.13 & & 0.2 & 0.66 & & 0.45 & \\
\hline Pro & 10.5 & 12.1 & 0.66 & \# & 1.7 & 0.16 & & 0.64 & 0.84 & & 0.59 & \\
\hline Ser & 7.5 & 8.6 & 0.33 & $\wedge$ & 2.3 & 0.46 & & 1.6 & 0.95 & \# & 0.87 & \\
\hline Thr & 9.5 & 11.3 & 0.11 & * & 1.8 & 0.24 & $\wedge$ & 1.2 & 0.55 & \# & 0.58 & \\
\hline Trp & 7.6 & 7.7 & 0.31 & & & & & & & & & \\
\hline Tyr & 11.3 & 12.1 & 0.45 & & & & & & & & & \\
\hline Val & 31.8 & 37.9 & 1.6 & $\wedge$ & 1.04 & 0.21 & & 0.4 & 1.02 & & 0.68 & \\
\hline TEAA & 134.8 & 154.8 & 4.8 & $\wedge$ & 14.4 & 1.12 & * & 10.8 & 3.63 & \# & 6.4 & \\
\hline TNEAA & 391.8 & 136.5 & 5.1 & $\wedge$ & 50.4 & 4.71 & * & 46.9 & 4.59 & $*$ & 5.7 & \\
\hline TAA & 257 & 291.3 & 6.8 & * & 64.4 & 5.28 & * & 57.7 & 6.33 & * & 11.8 & \\
\hline
\end{tabular}

${ }^{1}$ Cit $=$ citrulline Hyp $=$ hydroxyproline Orn = ornithine TEAA $=$ total essential AA; TNEAA = total nonessential AA; TAA = total AA.

${ }^{2}$ All FAA concentrations differ $(P<0.05)$ from zero. Differs from zero at $* P<0.001$ to $0.05, \wedge P<0.05$ to 0.1 , or ${ }^{\#} P<0.11$ to 0.2 (trend), respectively.

${ }^{3}$ Standard error of the model least squares means.

${ }^{4}$ Significance of difference between treatments within pools, at levels $* P<0.001$ to $0.05, \wedge P<0.05$ to 0.1 , or ${ }^{\#} P<0.11$ to 0.2 (trend), respectively.

${ }^{5}$ Standard error of the mean.

${ }^{6}$ Significance of difference from zero, at levels $* P<0.001$ to $0.05,{ }^{\wedge} P<0.05$ to 0.1 , or ${ }^{\#} P<0.11$ to 0.2 (trend), respectively.

Among the PBAA, only PB-Glu and PB-Gly differed from zero in both treatments $(P<0.02$ to 0.1$)$. Splanchnic flux of PB-His in SFS-fed cows was the only PBEAA whose flux differed from zero $(P<0.05)$ and tended to differ $(P<0.13)$ from its splanchnic flux in DRSfed cows.

Mammary Flux (Mammary Flux = MU). The MU of the free EAA Arg, Ile, Leu, Lys, and Trp were similar for both treatments, whereas uptakes of His, Met, Phe, Thr, and Val were numerically higher, by 6 to $10 \%$, in cows fed the SFS diets (Table 10). Nevertheless, MU of NEAA was numerically higher in most cases in cows fed the SFS diets, and higher than the total by approximately $17 \%$. The MU of all FAA, except for Gly in both treatments, and Asp, citrulline, and hydroxyproline in cows fed the DRS diets, differed from zero $(P<0.01$ to $0.05)$. The MU of PB-His differed from zero $(P<0.05)$ in DRS-fed cows only, as well as between treatments
$(P<0.05)$. The only EAA whose MU differed significantly from zero in both treatments was PB-Lys $(P<$ 0.01 ), but no difference between treatments was recorded. Peptide-bound Lys constituted 16.1 and 19.9\% of total MU of this AA in cows fed the SFS and DRS diets, respectively, which was much higher than any other EAA. The MU of PB-Ala and PB-ornithine differed from zero $(P<0.05$ to 0.1$)$ in both treatments, and these constituted approximately 29 to $45 \%$, respectively, of the total uptake of these AA (free $+\mathrm{PB}$ ). The MU of PB-Asp and PB-Ser in cows fed the SFS diet were different from zero $(P<0.05)$ and contributed a substantial proportion of the total MU of these AA. Significant uptake of PB-Glu was recorded in DRS-fed cows. Total MU of free EAA + PB-EAA was similar for most of the individual AA. However, a slight increase in uptake by SFS-fed cows, although not significant, was observed for His, Ile, Met, Thr, and Val. 
Table 6. Mammary vein concentrations (mg/L plasma) of free (F) and peptide-bound (PB) AA in plasma of cows fed steam-flaked (SFS) or dry-rolled (DRS) sorghum grain diets (n = 8)

\begin{tabular}{|c|c|c|c|c|c|c|c|c|c|c|c|c|}
\hline \multirow[b]{3}{*}{$\mathrm{AA}^{1}$} & \multicolumn{4}{|c|}{$\mathrm{FAA}^{2}$} & \multicolumn{6}{|c|}{ PBAA } & \multirow[b]{3}{*}{$\mathrm{SEM}^{3}$} & \multirow[b]{3}{*}{$P<<^{4}$} \\
\hline & \multirow{2}{*}{$\begin{array}{l}\text { SFS, } \\
\text { mean }\end{array}$} & \multirow{2}{*}{$\begin{array}{l}\text { DRS, } \\
\text { mean }\end{array}$} & \multirow[b]{2}{*}{$\mathrm{SEM}^{3}$} & \multirow[b]{2}{*}{$P<^{4}$} & \multicolumn{3}{|c|}{ SFS } & \multicolumn{3}{|c|}{ DRS } & & \\
\hline & & & & & Mean & $\mathrm{SEM}^{5}$ & $P<^{6}$ & Mean & SEM $^{5}$ & $P<^{6}$ & & \\
\hline Ala & 15.53 & 17.47 & 0.69 & $\wedge$ & 1.98 & 0.3 & * & 2.23 & 0.65 & * & 0.41 & \\
\hline Arg & 4.52 & 5.19 & 0.35 & & 0.52 & 0.09 & $*$ & 0.81 & 0.27 & $*$ & 0.2 & \\
\hline Asn & 1.68 & 1.54 & 0.39 & & & & & & & & & \\
\hline Asp & 1.84 & 2.39 & 0.16 & * & 1.87 & 0.22 & $*$ & 2.37 & 0.55 & * & 0.29 & \\
\hline Cit & 13.34 & 15.83 & 0.52 & $*$ & & & & & & & & \\
\hline Gln & 10.81 & 13.3 & 1.13 & \# & & & & & & & & \\
\hline Glu & 1.59 & 1.84 & 0.14 & & 9.54 & 0.38 & $*$ & 13.91 & 1.38 & * & 0.29 & $*$ \\
\hline Gly & 16.61 & 17.25 & 0.94 & & 25.45 & 1.98 & $*$ & 29.12 & 2.1 & * & 1.3 & \# \\
\hline His & 3.41 & 3.42 & 0.19 & & 3.03 & 0.34 & $*$ & 3.26 & 0.35 & * & 0.17 & \\
\hline Нур & 1.81 & 1.94 & 0.09 & & 1.15 & 0.11 & * & 1.11 & 0.1 & * & 0.095 & \\
\hline Ile & 9.34 & 11.22 & 0.87 & \# & 0.07 & 0.15 & & 0.42 & 0.26 & \# & 0.25 & \\
\hline Leu & 12.28 & 15.24 & 0.99 & $\wedge$ & 1.33 & 0.24 & $\wedge$ & 1.86 & 0.67 & * & 0.56 & \\
\hline Lys & 2.43 & 2.53 & 0.25 & & 1.1 & 0.14 & $*$ & 1.76 & 0.33 & $*$ & 0.23 & $\wedge$ \\
\hline Met & 0.28 & 0.38 & 0.08 & & 0.9 & 0.28 & $*$ & 1.27 & 0.36 & $*$ & 0.25 & \\
\hline Orn & 1.6 & 1.84 & 0.09 & \# & 1.57 & 0.22 & $*$ & 2.03 & 0.31 & * & 0.13 & $*$ \\
\hline Phe & 4.48 & 5.08 & 0.27 & & 0.23 & 0.04 & $\wedge$ & 0.37 & 0.17 & * & 0.1 & \\
\hline Pro & 7.08 & 8.18 & 0.53 & \# & 1.38 & 0.09 & * & 1.66 & 0.18 & * & 0.13 & \# \\
\hline Ser & 3.83 & 4.11 & 0.20 & & 1.81 & 0.1 & $*$ & 2.54 & 0.87 & $\wedge$ & 0.64 & \\
\hline Thr & 4.97 & 6.39 & 0.26 & * & 0.87 & 0.17 & $*$ & 1.19 & 0.28 & * & 0.23 & \\
\hline Trp & 5.56 & 5.6 & 0.15 & & & & & & & & & \\
\hline Tyr & 5.87 & 6.71 & 0.40 & \# & & & & & & & & \\
\hline Val & 22.64 & 25.92 & 1.63 & & 0.91 & 0.19 & $*$ & 1.01 & 0.23 & $*$ & 0.2 & \\
\hline TEAA & 69.9 & 81.0 & 3.9 & $\wedge$ & 9.0 & 1.16 & $*$ & 11.95 & 2.25 & $*$ & 1.95 & \# \\
\hline TNEAA & 81.6 & 92.4 & 3.00 & * & 44.8 & 3.45 & * & 54.97 & 4.09 & * & 0.31 & $*$ \\
\hline TAA & 151.5 & 173.4 & 6.6 & $\wedge$ & 53.8 & 3.97 & $*$ & 66.92 & 6.08 & * & 0.45 & $*$ \\
\hline
\end{tabular}

${ }^{1}$ Cit $=$ citrulline Hyp $=$ hydroxyproline Orn = ornithine TEAA $=$ total essential AA; TNEAA $=$ total nonessential AA; TAA = total AA.

${ }^{2}$ All FAA concentrations differ $(P<0.05)$ from zero. Differs from zero at $* P<0.001$ to $0.05, \wedge P<0.05$ to 0.1 , or ${ }^{\#} P<0.11$ to 0.2 (trend), respectively.

${ }^{3}$ Standard error of the model least squares means.

${ }^{4}$ Significance of difference between treatments within pools, at levels ${ }^{*} P<0.001$ to $0.05,{ }^{\wedge} P<0.05$ to 0.1 , or ${ }^{\#} P<0.11$ to 0.2 (trend), respectively.

${ }^{5}$ Standard error of the mean.

${ }^{6}$ Significance of difference from zero, at levels ${ }^{*} P<0.001$ to $0.05,{ }^{\wedge} P<0.05$ to 0.1 , or ${ }^{\#} P<0.11$ to 0.2 (trend), respectively.

\section{Mammary Extraction Efficiency}

Eight out of 10 EAA in the FAA pool were extracted slightly more efficiently by cows fed the SFS diet (Table 11). However, only the extraction of Thr was significantly higher $(P<0.04)$ in these cows than in their DRS-fed counterparts. Both Lys and Trp were extracted more efficiently by DRS-fed cows. This result was reversed for PB-Lys, which was extracted more efficiently by SFS-fed cows. Differences in NEAA extraction exhibited the same trend as EAA, also with no significant differences except for PB-Asp, which was extracted more efficiently by cows fed the SFS diet.

\section{AA Secreted in Milk}

Secretion in milk of Arg, Ile, Leu, Met, and Val was slightly or much lower than their uptake from the artery (Table 10). Secretion of His, Phe, and Thr in SFS- fed cows was similar to the amounts extracted from the plasma. Secretion of Lys in milk was greater than the amounts extracted from the plasma by approximately 20 and $10 \%$ in cows fed the SFS or DRS diets, respectively, and secretion of Thr in milk from cows fed the DRS diets was approximately 10\% higher than the amounts extracted from both plasma pools.

\section{DISCUSSION}

\section{DMI and Dietary Efficiency}

Average DMI of SFS-fed cows for the entire experimental period was lower by approximately $4.4 \%$, or by approximately $12.8 \%$ with the last 3 sampling days included (Figure 1). The decrease in intake of other nutrients was also obviously lower to the same extent, except for the intake of $\mathrm{NE}_{\mathrm{L}}$ because of the steam-flaking effect. The rate of starch hydrolysis by amyloglucosi- 
TAGARI ET AL.

Table 7. Portal-drained viscera flux ( $\mathrm{g} / 12 \mathrm{~h}$ ) of free $(\mathrm{F})$ and peptide-bound (PB) AA in plasma of cows fed steam-flaked (SFS) or dry-rolled (DRS) sorghum grain diets $(\mathrm{n}=8)$

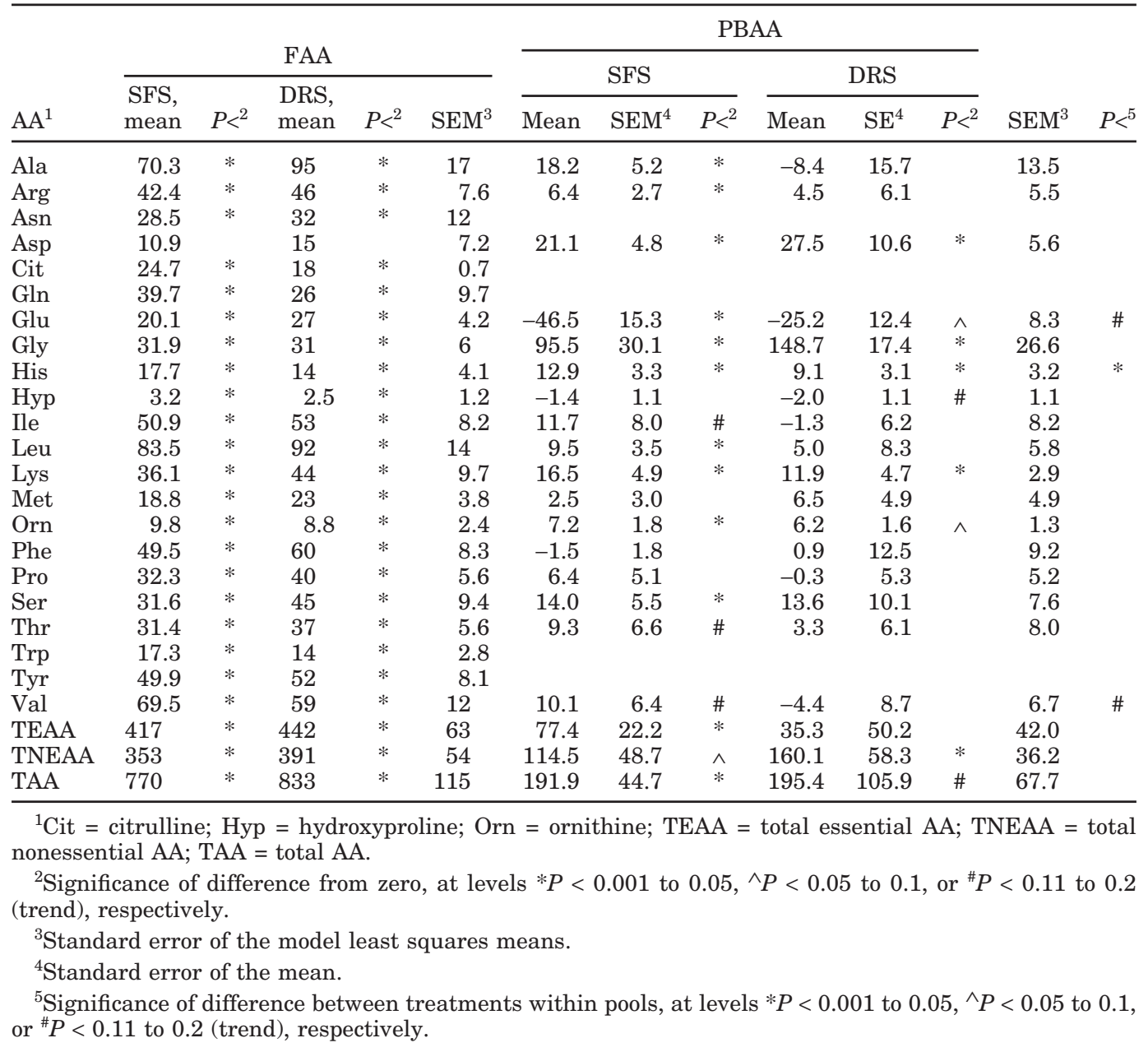

dase, as shown in our previous study, was much higher in the SFS grain compared with that in the DRS grain (65.6\% in SFS vs. $24.4 \%$ in DRS; Delgado-Elorduy et al., 2002a). The calculated $\mathrm{NE}_{\mathrm{L}}$ of the SFS diet was approximately 9\% higher than that of the DRS diet. Consequently, the decrease in intake of calculated energy in the SFS diet vs. the DRS diet was marginal.

In many comparisons, the average DMI of SFS has been found to be similar to that of DRS (Theurer et al., 1999). However, a decrease in the DMI of diets that contain substantial amounts of processed grain, as in the present experiment, is not uncommon. Santos et al. (1997a) reported a decrease of approximately 10\% in DMI of diets containing $40 \%$ sorghum grain steamflaked to densities of 437 or $360 \mathrm{~g} / \mathrm{L}$, compared with cows fed diets containing $40 \%$ DRS. That decrease did not jeopardize milk yield performance. More intensive steam-flaking of the sorghum grain, to a density of 283 $\mathrm{g} / \mathrm{L}$, further decreased DMI, but then it was accompanied by a significant decrease in milk yield (Santos et al., 1997a). In a second experiment, in which steamflaking of sorghum grain was examined (Santos et al. 1997b), buffers were added to the diet from the beginning of the experiment. The decrease in DMI was again observed, but with no jeopardizing effect on milk yield, even with the diet containing SFS to a density of 283 g/L. Moreover, Z. Shabi (Aminolab, Nes-Ziona, Israel; personal communication) reported a severe decrease in DMI when extruded corn grain supplied all the dietary corn grain, relative to coarsely ground corn grain. When the extruded grain replaced only $50 \%$ of the ground grain, the DMI decreased by only $7 \%$ relative to the diet containing ground corn only (Shabi et al., 1999); however, performance with respect to milk and milk protein yields was unaffected only when cows were fed 4 times daily. It was suggested that, in that case, the animals' buffering potential was hindered when starch availability for rumen fermentation was maximized, but an increased feed service, to 4 times daily, reduced that hindrance, which is in line with the results of 
Table 8. Liver flux of free (F) and peptide-bound (PB) AA (g/12 h) in plasma of cows fed steam-flaked (SFS) or dry-rolled (DRS) sorghum grain diets $(\mathrm{n}=5)$

\begin{tabular}{|c|c|c|c|c|c|c|c|c|c|c|c|c|c|c|}
\hline \multirow[b]{3}{*}{$\mathrm{AA}^{1}$} & \multirow{2}{*}{\multicolumn{6}{|c|}{ FAA }} & \multicolumn{6}{|c|}{ PBAA } & \multirow[b]{3}{*}{$\mathrm{SEM}^{3}$} & \multirow[b]{3}{*}{$P<5$} \\
\hline & & & & & & & \multicolumn{3}{|c|}{ SFS } & \multicolumn{3}{|c|}{ DRS } & & \\
\hline & $\begin{array}{l}\text { SFS, } \\
\text { mean }\end{array}$ & $P<^{2}$ & $\begin{array}{l}\text { DRS, } \\
\text { mean }\end{array}$ & $P<^{2}$ & $\mathrm{SEM}^{3}$ & $P<^{5}$ & Mean & $\mathrm{SEM}^{4}$ & $P<^{2}$ & Mean & $\mathrm{SEM}^{4}$ & $P<^{2}$ & & \\
\hline Ala & -52.3 & * & -41.9 & $\wedge$ & 4.4 & \# & -4.6 & 5.4 & & -26.2 & 11.6 & $\wedge$ & 8.0 & \# \\
\hline Arg & -10.1 & & -7.5 & & 5.2 & & 2.1 & 7.6 & & -3.4 & 6.7 & & 5.3 & \\
\hline Asn & -30.9 & * & -5.3 & & 12.4 & & & & & & & & & \\
\hline Asp & 4.3 & & -3.9 & & 8.8 & & -14.1 & 13.8 & & -3.4 & 20.4 & & 12.1 & \\
\hline Cit & -13.2 & & -6.4 & & 12.5 & & & & & & & & & \\
\hline Gln & -40.6 & & -35.3 & * & 24.5 & & & & & & & & & \\
\hline Glu & 64.7 & * & -42.1 & * & 4.6 & $*$ & -41.8 & 32.8 & & -82.6 & 28.6 & $*$ & 29.4 & \\
\hline Gly & -42.3 & * & -26.4 & & 11.2 & & 42.7 & 35.9 & & -21.4 & 22.3 & & 32.5 & \# \\
\hline $\mathrm{His}$ & -11.0 & \# & 2.1 & & 3.7 & \# & 19.6 & 13.1 & & -6.6 & 11.8 & & 8.0 & $\wedge$ \\
\hline Нур & -4.1 & \# & -2.7 & & 2.0 & & 1.8 & 0.7 & $\wedge$ & 2.5 & 1.7 & & 1.2 & \\
\hline Ile & -1.4 & & 8.0 & & 5.3 & & -3.5 & 5.8 & & -35.4 & 20.3 & \# & 15.4 & \\
\hline Leu & -0.4 & & -1.9 & & 9.8 & & 1.3 & 8.5 & & -22.7 & 12.1 & & 10.8 & \\
\hline Lys & 3.6 & & -5.6 & & 6.3 & & 2.0 & 10.8 & & -0.1 & 4.8 & & 11.6 & \\
\hline Met & -5.4 & & -4.5 & & 2.3 & & 1.6 & 2.8 & & -2.2 & 2.2 & $\wedge$ & 3.7 & \# \\
\hline Orn & 2.5 & & 1.0 & & 2.3 & & 5.4 & 5.9 & & -1.4 & 4.1 & & 6.9 & \\
\hline Phe & -28.3 & * & -34.8 & $*$ & 4.2 & & 4.5 & 2.1 & $\wedge$ & 5.4 & 7.5 & & 4.7 & \\
\hline Pro & -12.8 & * & -10.2 & & 3.6 & & 0.2 & 4.8 & & -12.7 & 5.7 & & 3.5 & $\wedge$ \\
\hline Ser & -25.4 & * & -26.3 & $*$ & 3.5 & & -0.4 & 14.4 & & -32.6 & 13.2 & $\wedge$ & 8.8 & $\wedge$ \\
\hline Thr & -17.4 & $\wedge$ & -9.0 & & 4.4 & & 9.0 & 8.0 & & -7.0 & 9.9 & & 8.2 & \\
\hline Trp & -8.5 & $\wedge$ & -8.6 & \# & 3.3 & & & & & & & & & \\
\hline Tyr & -28.6 & * & -27.0 & $\wedge$ & 4.5 & & & & & & & & & \\
\hline Val & -14.3 & & -2.6 & & 16.2 & & -3.0 & 5.2 & & -5.4 & 9.7 & & 5.3 & \\
\hline TEAA & -93.1 & * & -64.2 & & 29.0 & & 33.7 & 18.7 & & -77.2 & 54.4 & \# & 25.3 & $*$ \\
\hline TEAA $^{6}$ & & & & & & & 40.1 & 10.2 & & 5.4 & 7.5 & & 8.9 & $*$ \\
\hline TNEAA & -177.7 & $\wedge$ & -226.4 & $\wedge$ & 47.8 & & -10.8 & 124.0 & & -177.7 & 35.5 & \# & 85.1 & \\
\hline TAA & -271.8 & $\wedge$ & -290.6 & $*$ & 53.0 & & 22.8 & 169.5 & & -255.0 & 80.7 & $*$ & 85.0 & \# \\
\hline
\end{tabular}

${ }^{1}$ Cit $=$ citrulline; Hyp = hydroxyproline; Orn = ornithine; TEAA = total essential AA; TNEAA = total nonessential AA; TAA = total AA.

${ }^{2}$ Significance of difference from zero, at levels ${ }^{*} P<0.001$ to $0.05, \wedge P<0.05$ to 0.1 , or ${ }^{\#} P<0.11$ to 0.2 (trend), respectively.

${ }^{3}$ Standard error of the model least squares means.

${ }^{4}$ Standard error of the mean.

${ }^{5}$ Significance of difference between treatments within pools, at levels $* P<0.001$ to $0.05, \wedge P<0.05$ to 0.1 , or ${ }^{\#} P<0.11$ to 0.2 (trend), respectively.

${ }^{6}$ Positive values only.

Santos et al. (1997b) when a buffer was added to extremely steam-flaked sorghum diets. In the present experiment, the sorghum grain was steam-flaked only to a density of $360 \mathrm{~g} / \mathrm{L}$, which is not an extreme steamflaking. It may be concluded that the decrease in feed intake was caused either by the energy needs being satisfied because of increased energy availability or by the high feed intake in the previous days.

In the present experiment, milk secretion of total EAA by SFS-fed cows (190 g/12 h) exceeded that by DRS-fed cows $(175.1 \mathrm{~g} / 12 \mathrm{~h})$ by 8.6 and $8.8 \%$, respectively, for total AA (Table 10). These differences corresponded well with the difference in total milk-CP yield, and despite their lack of statistical significance, are noteworthy, probably real, and as such, need to be explained.

The decrease in DMI by SFS-fed cows in the last 72 $\mathrm{h}$ prior to and on the sampling day (Figure 1) should decrease the ruminal outflow of digesta, which is the only source of absorbable protein components, and this should be followed by a decrease in the PDVF of protein components. Indeed, PDVF of FAA appeared to be lower in the SFS-fed cows. However, in those same cows, PDVF of PBAA appeared to be higher, and differed from zero $(P<0.05)$, resulting in a marginally higher flux of FAA + PBAA in SFS-fed cows for most EAA. Accordingly, milk performance, AA secretion included, did not decrease. We therefore suggest that the balancing effect of the AA supply from the PBAA pool compensated for the shortage of AA from the FAA pool for milk protein production. The same mechanism was probably involved in the aforementioned trials of Santos et al. (1997a,b) and Shabi et al. (1999) in which, as in the current study, despite a decrease in DMI, milk yield did not decrease. The higher share of PBAA pool in the $\mathrm{PDVF}$ and its capability to meet the AA requirements 
Table 10. Mammary uptake ( $\mathrm{g} / 12 \mathrm{~h}$ ) of free (F) and peptide-bound (PB) AA from plasma, and milk AA secretion (g/12 h) of cows fed steamflaked (SFS) or dry-rolled (DRS) sorghum grain diets $(\mathrm{n}=8)$

\begin{tabular}{|c|c|c|c|c|c|c|c|c|c|c|c|c|c|c|c|c|c|c|}
\hline \multirow[b]{3}{*}{$\mathrm{AA}^{1}$} & \multirow{2}{*}{\multicolumn{6}{|c|}{ FAA }} & \multicolumn{8}{|c|}{ PBAA } & \multirow{2}{*}{\multicolumn{4}{|c|}{ AA secreted in milk, $\mathrm{g} / 12 \mathrm{~h}$}} \\
\hline & & & & & & & \multicolumn{3}{|c|}{ SFS } & \multicolumn{3}{|c|}{ DRS } & \multirow[b]{2}{*}{$\mathrm{SEM}^{3}$} & \multirow[b]{2}{*}{$P<^{5}$} & & & & \\
\hline & $\begin{array}{l}\text { SFS, } \\
\text { mean }\end{array}$ & $P<^{2}$ & $\begin{array}{l}\text { DRS, } \\
\text { mean }\end{array}$ & $P<<^{2}$ & $\mathrm{SEM}^{3}$ & $P<5$ & Mean & $\mathrm{SEM}^{4}$ & $P<^{2}$ & Mean & $\mathrm{SEM}^{4}$ & $P<^{2}$ & & & $\begin{array}{l}\text { SFS, } \\
\text { mean }\end{array}$ & $\begin{array}{l}\text { DRS, } \\
\text { mean }\end{array}$ & $\mathrm{SEM}^{3}$ & $P<5$ \\
\hline Ala & 14.5 & $*$ & 8.1 & $*$ & 3.7 & & 3.4 & 1.8 & $\wedge$ & 3.7 & 1.8 & $*$ & 1.5 & & 11.3 & 10.3 & 0.5 & \# \\
\hline Arg & 25.4 & * & 24.5 & * & 0.9 & & -0.1 & 0.8 & & 1.3 & 1.3 & & 1.4 & & 14.1 & 12.8 & 0.6 & \# \\
\hline Asn & 9.3 & $*$ & 4.6 & $*$ & 2.4 & & & & & & & & & & & & & \\
\hline Asp & 4.9 & $*$ & 6.5 & & 1.6 & & 6.7 & 1.6 & * & -0.4 & 2.7 & & 2.5 & $\wedge$ & 27.9 & 25.8 & 1.2 & \\
\hline Glu & 27.1 & $*$ & 26.2 & * & 1.8 & & -4.7 & 9.1 & & -22.6 & 10.4 & $\wedge$ & 10.4 & & 82.3 & 75.8 & 3.5 & \\
\hline Gly & 2.9 & & 1.1 & & 2.0 & & 2.6 & 3.6 & & -10.6 & 8.0 & & 7.9 & & 6.1 & 5.5 & 0.3 & \# \\
\hline His & 10.3 & $*$ & 8.6 & $*$ & 0.9 & & 0.4 & 0.3 & & 1.6 & 0.3 & $*$ & 0.3 & * & 10.9 & 9.8 & 0.4 & $\wedge$ \\
\hline Нур & 0.0 & & -0.1 & & 0.3 & & -0.02 & 0.3 & & -0.3 & 0.3 & & 0.3 & & & & & \\
\hline Ile & 26.9 & $*$ & 26.5 & * & 1.5 & & -0.01 & 1.1 & & -0.8 & 1.5 & & 1.8 & & 21.8 & 20.1 & 1.0 & \\
\hline Leu & 45.7 & $*$ & 46.7 & $*$ & 2.2 & & 1.2 & 0.9 & & -0.5 & 3.6 & & 3.1 & & 37.9 & 35.1 & 1.7 & \\
\hline Lys & 22.6 & $*$ & 22.7 & * & 1.2 & & 4.7 & 1.3 & * & 5.4 & 1.4 & $*$ & 1.5 & & 33.0 & 30.5 & 1.4 & \\
\hline Thr & 15.8 & $*$ & 13.5 & $*$ & 0.9 & \# & 0.4 & 1.1 & & 0.6 & 1.5 & & 1.5 & & 16.8 & 15.7 & 0.7 & \\
\hline Trp & 6.0 & $*$ & 6.1 & $*$ & 0.6 & & & & & & & & & & & & & \\
\hline Tyr & 18.9 & $*$ & 18.1 & $*$ & 1.1 & & & & & & & & & & 20.6 & 18.8 & 0.9 & \# \\
\hline Val & 31.3 & * & 29.4 & $*$ & 2.6 & & -0.2 & 1.1 & & 0.1 & 1.7 & & 1.7 & & 24.7 & 22.8 & 1.0 & \\
\hline TEAA $^{6}$ & 216.5 & $*$ & 207.5 & $*$ & 8.7 & & 8.0 & 7.7 & & 10.2 & 13.7 & & 16.1 & & 190.0 & 175.2 & 8.0 & \\
\hline $\mathrm{TEAA}^{7}$ & & & & & & & 8.8 & & & 11.5 & & & & & & & & \\
\hline TNEAA & 127.9 & $*$ & 108.9 & $*$ & 12.1 & & 15.7 & 20.1 & & 26.5 & 38.9 & \# & 29.4 & \# & 205.6 & 188.6 & 8.9 & \\
\hline TAA & 344.4 & $*$ & 316.4 & * & 19.6 & & 23.7 & 26.1 & & 16.3 & 28.7 & & 44.1 & & 395.6 & 363.8 & 16.7 & \\
\hline
\end{tabular}

${ }^{1} \mathrm{Cit}=$ citrulline; Hyp = hydroxyproline; Orn = ornithine; TEAA = total essential AA; TNEAA = total nonessential AA; TAA = total AA.

${ }^{2}$ Significance of difference from zero, at levels $* P<0.001$ to $0.05, \wedge P<0.05$ to 0.1 , or ${ }^{\#} P<0.11$ to 0.2 (trend), respectively.

${ }^{3}$ Standard error of the model least squares means.

${ }^{4}$ Standard error of the mean.

${ }^{5}$ Significance of difference between treatments within pools, at levels ${ }^{*} P<0.001$ to $0.05,{ }^{\wedge} P<0.05$ to 0.1 , or ${ }^{\#} P<0.11$ to 0.2 (trend), respectively.

${ }^{6}$ Negative values included.

${ }^{7}$ Positive uptakes only.

amounts of $\mathrm{CO}_{2}$, thereby leading to greater amounts of recycled urea in SFS-fed cows, as reported previously by Delgado-Elorduy et al. (2002b) and by Al-Dehne et al. (1997), who showed an increase in microbial protein synthesis with increased urea recycling into the rumen. It may therefore be concluded that the lower DMI of cows fed the SFS diets does not jeopardize their performance protein-wise, equalizing it with cows fed the DRS diets. Furthermore, this performance was maintained by a higher, compensatory urea recycling rate and more efficient and enhanced microbial protein synthesis in the rumen, and not by drawing CP components from body reserves. Compensation was expressed in the PDVF in the PBAA pool rather than in the FAA pool.

Another compensatory factor, although probably small, may be the better digestion and nutrient absorption resulting from the diminished feed intake of the SFS diet vs. the DRS diet. This decrease amounted to approximately two-thirds of one maintenance level, which, according to the NRC (1989), may improve digestibility of DM by approximately $3 \%$, in addition to the improved digestibility conferred by steam-flaking. In support, Bar-Peled et al. (1998) observed increased digestibilities of 2 and $5 \%$ in cows milked 6 times a day or milked 3 times with 3 sucklings per day, respectively. Both of these groups were in great need of nutrients, as compared with cows milked 3 times daily.

It may therefore be concluded that steam-flaking of sorghum grain enhanced the dietary nitrogen utilization of SFS diets, and together with more aggressive fermentation and absorption, compensated for the lower feed and CP intake, thereby equalizing the performance of SFS-fed cows to that of DRS cows, despite the lower feed intake of the former.

\section{The Source of PBAA in PDV}

It is common knowledge that without the use of specific markers such as ${ }^{15} \mathrm{~N}$ or ${ }^{14} \mathrm{C}$, it is impossible to 
Table 11. Mammary extraction efficiency (\%) of free (F) and peptide-bound (PB) AA ( $g / 12 \mathrm{~h}$ ) from plasma of cows fed steam-flaked (SFS) or dry-rolled (DRS) sorghum grain diets $(\mathrm{n}=8)$

\begin{tabular}{|c|c|c|c|c|c|c|c|c|c|c|c|c|c|c|}
\hline \multirow[b]{3}{*}{$\mathrm{AA}^{1}$} & \multirow{2}{*}{\multicolumn{6}{|c|}{ FAA }} & \multicolumn{6}{|c|}{ PBAA } & \multirow[b]{3}{*}{$\mathrm{SEM}^{3}$} & \multirow[b]{3}{*}{$P<^{5}$} \\
\hline & & & & & & & \multicolumn{3}{|c|}{ SFS } & \multicolumn{3}{|c|}{ DRS } & & \\
\hline & $\begin{array}{l}\text { SFS, } \\
\text { mean }\end{array}$ & $P<^{2}$ & $\begin{array}{l}\text { DRS, } \\
\text { mean }\end{array}$ & $P<^{2}$ & $\mathrm{SEM}^{3}$ & $P<^{5}$ & Mean & $\mathrm{SEM}^{4}$ & $P<^{2}$ & Mean & $\mathrm{SEM}^{4}$ & $P<^{2}$ & & \\
\hline Ala & 16.6 & * & 10.9 & $\wedge$ & 4.1 & & 11.1 & 16.0 & & 27.2 & 13.5 & $\wedge$ & 15.9 & \\
\hline Arg & 54.3 & * & 51.9 & * & 3.2 & & -309.7 & 227.2 & & -6.8 & 42.5 & & 169.6 & \\
\hline Asn & 57.8 & * & 30.0 & & 63.1 & & & & & & & & & \\
\hline Asp & 36.2 & $*$ & 35.1 & $*$ & 6.4 & & 39.4 & 7.5 & * & -37.4 & 40.6 & & 28.6 & $\wedge$ \\
\hline Cit & 4.0 & $*$ & 3.4 & & 3.3 & & & & & & & & & \\
\hline Gln & 21.6 & $*$ & 15.7 & & 4.2 & & & & & & & & & \\
\hline Glu & 77.8 & $*$ & 75.3 & $*$ & 1.9 & & -38.2 & 21.6 & \# & -95.7 & 32.1 & $*$ & 26.6 & \# \\
\hline Gly & 3.9 & \# & 0.5 & & 2.4 & & 2.4 & 2.8 & & -7.1 & 5.8 & & 5.5 & \\
\hline His & 37.8 & $*$ & 35.8 & $*$ & 1.7 & & 198.9 & 155.5 & $\wedge$ & 7.2 & 11.0 & & 112.5 & \\
\hline Нур & -0.2 & & -0.6 & & 3.2 & & -2.8 & 5.3 & & -6.1 & 5.2 & & 4.9 & \\
\hline Ile & 37.4 & * & 35.1 & * & 3.1 & & 60.3 & 64.0 & & -288.3 & 169.8 & \# & 154.7 & \# \\
\hline Leu & 44.0 & $*$ & 41.0 & $*$ & 2.0 & & 18.7 & 9.8 & $\wedge$ & -7.1 & 35.7 & & 28.5 & \\
\hline Lys & 65.9 & $*$ & 67.0 & $*$ & 2.4 & & 43.1 & 9.7 & * & 41.9 & 8.9 & $*$ & 9.9 & \\
\hline Met & 93.5 & $*$ & 89.2 & $*$ & 2.6 & & -16.2 & 64.0 & & 23.5 & 20.8 & & 43.3 & \\
\hline Orn & 50.8 & $*$ & 50.7 & $*$ & 2.4 & & 30.3 & 5.9 & * & 30.3 & 6.6 & $*$ & 3.3 & \\
\hline Phe & 46.1 & $*$ & 44.2 & $*$ & 2.8 & & -99.6 & 109.5 & & 425.9 & 458.0 & & 350.3 & \\
\hline Pro & 23.0 & $*$ & 18.9 & $*$ & 3.2 & & 5.6 & 10.2 & & -12.8 & 14.8 & & 13.4 & \\
\hline Ser & 45.1 & $*$ & 42.1 & $*$ & 2.0 & & 24.0 & 9.2 & * & 7.0 & 30.7 & & 24.0 & \\
\hline Thr & 41.0 & $*$ & 33.0 & * & 2.2 & $*$ & 254.8 & 238.6 & & 0.9 & 32.1 & & 168.2 & \\
\hline Trp & 18.5 & $*$ & 19.4 & $*$ & 2.0 & & & & & & & & & \\
\hline Tyr & 41.1 & * & 38.2 & $*$ & 2.9 & & & & & & & & & \\
\hline Val & 22.9 & $*$ & 20.7 & $*$ & 2.7 & & -19.0 & 26.1 & & -22.0 & 45.1 & & 40.4 & \\
\hline TEAA & 39.1 & * & 36.6 & * & 2.2 & & -29.6 & 16.4 & & 19.5 & 18.5 & & 20.9 & \\
\hline TNEAA & 24.2 & * & 20.7 & $*$ & 2.0 & & -16.2 & 9.6 & & -11.8 & 17.0 & \# & 16.0 & \# \\
\hline TAA & 31.7 & * & 28.9 & * & 2.0 & & -11.5 & 10.9 & & 4.7 & 16.9 & & 17.1 & \\
\hline
\end{tabular}

${ }^{1}$ Cit $=$ citrulline Hyp $=$ hydroxyproline Orn $=$ ornithine $;$ TEAA $=$ total essential AA; TNEAA $=$ total nonessential AA; TAA = total AA.

${ }^{2}$ Significance of difference from zero, at levels $* P<0.001$ to $0.05,{ }^{\wedge} P<0.05$ to 0.1 , or ${ }^{\#} P<0.11$ to 0.2 (trend), respectively.

${ }^{3}$ Standard error of the model least squares means.

${ }^{4}$ Standard error of the mean.

${ }^{5}$ Significance of difference between treatments within pools, at levels $* P<0.001$ to $0.05, \wedge P<0.05$ to 0.1 , or ${ }^{\#} P<0.11$ to 0.2 (trend), respectively.

determine whether the portal appearance or disappearance of FAA or PBAA is the result of absorption from or secretion into the GIT lumen, or of the metabolism of the GIT wall (Remond et al., 2000b). It is accepted, however, that the PDVF is the result of amounts absorbed from the intestine and those of the FAA + PBAA inflow from the ruminal vein into the mesenteric vein, the latter being richer in PBAA (Seal and Parker, 1996). Fluxes of both veins form the PDVF that is driven into the liver for further metabolism and use.

Koeln et al. (1993) observed a greater PDVF of PBAA in fed vs. fasted calves and attributed this flux, in part at least, to absorption of peptides from the GIT lumen. Remond et al. (2000b) observed an increase in PDVF of PB-Ile, PB-Leu, and PB-Pro, as well as in total PBEAA, following an infusion of substantial amounts of hydrolyzed CN in addition to a control meal. These authors concluded that this increase in the flux of PBAA could be attributed, at least in part, to absorption of peptides from the GIT. In a recent study, Tagari et al.
(2004) reported that the large increase in PDVF of FAA in cows fed steam-flaked vs. steam-rolled corn grain diets was accompanied by an increase in 4 essential PBAA in the PDVF and an increasing trend for another 2 . In view of these 3 observations, it is suggested that those increases of the PBAA in PDVF may be attributed mainly to dietary effects. In the present study, despite the decrease in DMI during the last 3 experimental days, and despite the fact that this decrease was accompanied by a decrease in PDVF of FAA, the PDVF of individual PBAA was numerically larger in many more cases in cows fed the SFS diet vs. the DRS diet, totaling more than twice that determined in cows fed the DRS diet. Supporting the view that these differences may be real, even though they were not found to be significant, is the fact that many of the PBAA in the PDVF of cows fed the SFS diets differed from zero $(P<0.05)$, in contrast to cows fed the DRS diets, where they did not.

A possible explanation for this phenomenon, observed in our previous experiment (Tagari et al., 2004) 
Table 12. Milk secretion of AA (g/kg of DMI) for 2,3 , and $5 \mathrm{~d}$ prior to sampling

\begin{tabular}{|c|c|c|c|c|c|c|c|c|c|c|}
\hline \multirow[b]{2}{*}{$\mathrm{AA}$} & \multirow[b]{2}{*}{$\operatorname{Diet}^{1}$} & \multicolumn{3}{|c|}{ Last $2 \mathrm{~d}$} & \multicolumn{3}{|c|}{ Last $3 \mathrm{~d}$} & \multicolumn{3}{|c|}{ Average $5 \mathrm{~d}$} \\
\hline & & AA & SEM & $P<$ & AA & SEM & $P<$ & $\mathrm{AA}$ & SEM & $P<$ \\
\hline \multirow[t]{2}{*}{ Ala } & DRS & 0.568 & 0.053 & 0.049 & 0.566 & 0.042 & 0.036 & 0.581 & 0.015 & 0.038 \\
\hline & SFS & 0.755 & & & 0.726 & & & 0.639 & & \\
\hline \multirow[t]{2}{*}{ Arg } & DRS & 0.706 & 0.063 & 0.042 & 0.703 & 0.049 & 0.029 & 0.722 & 0.017 & 0.023 \\
\hline & SFS & 0.938 & & & 0.902 & & & 0.797 & & \\
\hline \multirow[t]{2}{*}{ Asp } & DRS & 1.428 & 0.131 & 0.057 & 1.423 & 0.102 & 0.044 & 1.459 & 0.035 & 0.049 \\
\hline & SFS & 1.861 & & & 1.789 & & & 1.579 & & \\
\hline \multirow[t]{2}{*}{ Glu } & DRS & 4.189 & 0.373 & 0.050 & 4.174 & 0.290 & 0.037 & 4.278 & 0.105 & 0.045 \\
\hline & SFS & 5.480 & & & 5.270 & & & 4.653 & & \\
\hline \multirow[t]{2}{*}{ Gly } & DRS & 0.303 & 0.028 & 0.042 & 0.302 & 0.022 & 0.031 & 0.310 & 0.007 & 0.017 \\
\hline & SFS & 0.404 & & & 0.388 & & & 0.342 & & \\
\hline \multirow[t]{2}{*}{ His } & DRS & 0.542 & 0.049 & 0.039 & 0.540 & 0.038 & 0.028 & 4.278 & 0.105 & 0.045 \\
\hline & SFS & 0.723 & & & 0.695 & & & 4.653 & & \\
\hline \multirow[t]{2}{*}{ Ile } & DRS & 1.112 & 0.103 & 0.057 & 1.108 & 0.081 & 0.045 & 1.137 & 0.033 & 0.081 \\
\hline & SFS & 1.455 & & & 1.398 & & & 1.234 & & \\
\hline \multirow[t]{2}{*}{ Leu } & DRS & 1.940 & 0.177 & 0.058 & 1.933 & 0.139 & 0.045 & 1.981 & 0.054 & 0.076 \\
\hline & SFS & 2.527 & & & 2.429 & & & 2.144 & & \\
\hline \multirow[t]{2}{*}{ Lys } & DRS & 1.684 & 0.140 & 0.042 & 1.679 & 0.108 & 0.030 & 1.720 & 0.048 & 0.069 \\
\hline & SFS & 2.196 & & & 2.114 & & & 1.869 & & \\
\hline \multirow[t]{2}{*}{ Met } & DRS & 0.541 & 0.048 & 0.053 & 0.538 & 0.037 & 0.039 & 0.552 & 0.016 & 0.078 \\
\hline & SFS & 0.704 & & & 0.677 & & & 0.599 & & \\
\hline \multirow[t]{2}{*}{ Phe } & DRS & 1.023 & 0.093 & 0.048 & 1.019 & 0.073 & 0.037 & 1.046 & 0.033 & 0.078 \\
\hline & SFS & 1.348 & & & 1.296 & & & 1.144 & & \\
\hline \multirow[t]{2}{*}{ Pro } & DRS & 2.147 & 0.194 & 0.046 & 2.138 & 0.151 & 0.034 & 2.190 & 0.056 & 0.037 \\
\hline & SFS & 2.832 & & & 2.722 & & & 2.402 & & \\
\hline \multirow[t]{2}{*}{ Ser } & DRS & 0.757 & 0.069 & 0.046 & 0.754 & 0.053 & 0.033 & 0.773 & 0.018 & 0.024 \\
\hline & SFS & 1.001 & & & 0.963 & & & 0.849 & & \\
\hline \multirow[t]{2}{*}{ Thr } & DRS & 0.870 & 0.080 & 0.069 & 0.866 & 0.063 & 0.055 & 0.888 & 0.020 & 0.072 \\
\hline & SFS & 1.121 & & & 1.078 & & & 0.949 & & \\
\hline \multirow[t]{2}{*}{ Tyr } & DRS & 1.040 & 0.095 & 0.049 & 1.037 & 0.075 & 0.037 & 1.062 & 0.029 & 0.046 \\
\hline & SFS & 1.371 & & & 1.318 & & & 1.164 & & \\
\hline \multirow[t]{2}{*}{ Val } & DRS & 1.261 & 0.114 & 0.056 & 1.256 & 0.089 & 0.042 & 1.289 & 0.035 & 0.076 \\
\hline & SFS & 1.643 & & & 1.580 & & & 1.395 & & \\
\hline \multirow[t]{2}{*}{ TEAA $^{2}$} & DRS & 9.679 & 0.866 & 0.051 & 9.644 & 0.572 & 0.038 & 9.889 & 0.264 & 0.062 \\
\hline & SFS & 12.654 & & & 12.169 & & & 10.744 & & \\
\hline \multirow[t]{2}{*}{$\mathrm{TAA}^{2}$} & DRS & 20.111 & 1.807 & 0.050 & 20.038 & 1.408 & 0.037 & 20.543 & 0.525 & 0.049 \\
\hline & SFS & 26.358 & & & 25.346 & & & 22.373 & & \\
\hline
\end{tabular}

${ }^{1} \mathrm{DRS}=$ dry-rolled sorghum grain diet; $\mathrm{SFS}=$ steam-flaked sorghum grain diet.

${ }^{2} \mathrm{TEAA}=$ total essential $\mathrm{AA} ; \mathrm{TAA}=$ total $\mathrm{AA}$.

and in the current study, may stem from the fact that the increase in microbial activity in the rumen of cows fed the steam-flaked grain may be accompanied by a different mode of degradation of dietary and microbial $\mathrm{CP}$ in the GIT, yielding more intermediate degradation products such as peptones and peptides, which flow out from the rumen to be absorbed in the rest of the GIT (omasum, abomasum, and intestine).

\section{The Interrelations Between FAA and PBAA Pools}

Totals. It has recently been suggested that the blood pool of PBAA may serve as a reserve AA pool, complementing the shortage of AA in the FAA pool (Lapierre et al., 2000). It may also be suggested that the distribution of AA between the 2 pools is the result of a balancing effect in the mode of their appearance along the studied fluxes. Starting with the PDVF, the totals of FAA + PBAA are fairly similar in both groups (Table
7). However, the number of AA or EAA that appear as PBAA whose quantities differed from zero $(P<0.05)$ was larger in cows fed the SFS diets than in DRSfed cows, and their quantities were numerically larger, which again, may be a result of a dietary effect.

That a greater negative liver flux of total AA (free + PB) was observed in cows fed the DRS diet indicates that the liver in these animals extracted more AA in a single pass or that AA uptake by the liver was greater (Table 8). Most of this difference was attributable to a greater uptake of PBAA $(P<0.11)$ in cows fed the DRS diet. It is of interest to note that there was essentially no uptake of PBAA in cows fed the SFS diet. When calves that weighed $136 \mathrm{~kg}$ were fed a diet composed mainly of ground corn grain, orchardgrass hay, soybean meal, and molasses, approximately $45 \%$ of FAA presented to the liver was taken up, in contrast to only approximately $7.5 \%$ of PBAA (Koeln et al., 1993). As noted, liver uptake of PBAA by cows fed the DRS was 
substantial, whereas it was virtually nonexistent in cows fed the SFS diet. This suggests the possible existence of a mechanism that controls uptake of PBAA by the liver depending on liver needs, the needs of extrahepatic tissues, or both.

This controlling mechanism that is involved in the distribution of the delivered AA between the FAA or PBAA pools is better exhibited in the splanchnic flux (Table 9), where the delivery of many of the EAA by the SFS-fed cows tended to be smaller than that in cows fed the DRS diet, but that of total PB-EAA was not only much greater $(P<0.04)$ in cows fed the SFS diet but also was a positive flux, as compared with a negative one in DRS-fed cows. The same applied to a considerable portion of the individual PBAA, but mostly as tendencies only.

Specific Cases, Balancing and Reserve Functions. The interrelations between Glu and PB-Glu and the inverted relations between Gly and PB-Gly in the PDVF are similar in both treatments (Table 7). A trend of interchange between Glu and PB-Glu was previously reported by Tagari et al. (2004). In view of the repeatability of the phenomenon, we suggest that PB-Glu serves as a reserve pool, supplementing the possible shortage of free Glu. A huge proportion in the PDVF was due to Gly. In certain cases, this AA may be an end-product of purine degredation, which is released from the breakdown of microbial cells. On the other hand, apart from being glucogenic, this AA is widely needed because it also serves as raw material for the composition of many body components such as glutathione, porphyrin, pteridine, riboflavin, and even back into purine. Its presence in the plasma in large quantities is assumed to cause osmolarity and imbalance problems, and this may induce the use of PB-Gly as a sink for the excess of free Gly. The PB-Gly content reached an extreme in splanchnic flux, where between 94 and 99\% of plasma Gly was in the form of PB-Gly (Table 9) and after dilution, it constituted approximately $60 \%$ of the arterial Gly + PB-Gly pools (Table 3). Another noteworthy case was His, which has recently been considered a limiting AA (Vanhatalo et al., 1999). The PDVF of His and PB-His in cows fed the SFS diets were higher by approximately 28 and $41 \%$, respectively, than in cows fed the DRS diets (Table 7). Further, LF of PBHis was positive and much higher $(P<0.1)$ in SFSfed cows. We suggest that in this case, free His was incorporated into the PB-His pool, resulting in a higher delivery of His in the PB form by the liver of cows fed the SFS diets (Table 8). This pattern was carried further, as expressed in the splanchnic flux of this PBHis (Table 9). It may be concluded that the shift between the 2 pools assists the organs in maintaining a balance between the free and reserve PB forms of supply of this or other AA. The same trend of maintaining a balance between the 2 pools along the 3 fluxes could be seen with the AA Thr, even though it was not always significant (Tables 7, 8, and 10). The smaller PDVF of Thr in SFSfed cows appeared to be compensated for by the PBThr flux, which was numerically nearly 3 times larger (Table 7) relative to DRS-fed cows. The greater liver uptake of Thr (Table 8) in SFS-fed cows appeared to be compensated for by an increased delivery of PB-Thr, resulting in the noteworthy equalizing effect of splanchnic flux of Thr in both treatments (Table 9).

The splanchnic flux of Arg appeared to be smaller in SFS-fed vs. DRS-fed cows, but the opposite was true for the PB-Arg pool. Although only the free Arg pools differed from zero $(P<0.05)$, the PB-Arg pools are worth mentioning because of their different magnitudes, which brought about a similar splanchnic flux of these AA in both treatments, thus supporting the notion of an equalizing effect (Table 9).

\section{Relationships Among FAA, PBAA, MU, and Milk Excretion of $A A$}

Mammary uptake of most FAA, especially certain essential ones, generally exceeds the quantities excreted in the milk. Those AA are used in part as milk protein precursors or in the production of other AA, such as Pro from Arg (Bruckental et al., 1991), or the use of Met to synthesize Cys, or other metabolic functions that were discussed previously (Tagari et al., 2004). Other free EAA, such as branched-chain AA, are extracted in excessive amounts by the mammary gland, and after incorporating the required amounts into the milk protein, the excesses are oxidized, as in the case of blood cell (BC) AA (Wholt et al., 1977; Roets et al., 1979). Nevertheless, some AA, such as His, Thr, or Trp, are transferred stoichiometrically into milk protein (Mepham, 1982). Accordingly, despite minor amounts of Phe that are converted to Tyr (Verbeke et al., 1967; Jorgenson and Larsen, 1968), most of the extracted amounts of both AA are completely used for milk protein production, and a shortage in their availability appears to activate their withdrawal from the PBAA pool.

\section{PBAA as a Reserve Pool for FAA in Milk Protein Production}

Results from in vivo experiments with lactating dairy goats using specific markers, such as ${ }^{15} \mathrm{~N}$ or ${ }^{14} \mathrm{C}$, indicate that many EAA are taken up by the mammary gland as PBAA from the circulation and utilized for protein synthesis (Backwell et al., 1997; Bequette et al., 1999). Mammary tissue from lactating cows was examined for 
the presence of mRNA for a peptide transport protein (PepT1; Chen et al., 1999). None was detected, indicating that utilization of PBAA by mammary tissue may not involve their absorption. However, recent evidence was reported for the presence of mRNA for aminopeptidase nitrogen in the mammary gland of goats and cows (Mabjeesh et al., 2005). This enzyme is imbedded in the basolateral side of the parechymal cells and not on the apical membrane, and is an exopeptidase that cleaves N-terminal AA from peptides, which may partly explain how AA from PBAA in the circulation are internalized by the mammary gland. In the present experiment, 2 indicators that PBAA serve as a reserve pool of EAA for milk protein synthesis may be as observed with His and Lys. The MU of His by SFS-fed cows almost matches the amounts excreted in milk by these cows (Table 10). In DRS-fed cows, MU of FAA-His was apparently lower compared with SFS-fed cows and did not meet the amounts needed for milk protein synthesis. We suggest that this concomitantly resulted in a significant mammary extraction $(P<0.01)$ of PB-His by DRS-fed cows, 4 times greater $(P<0.04)$ than that with SFS-fed cows, thus fully matching the need of DRS-fed cows for His secretion in milk. Similar use of the PB pool as a reserve was apparent regarding Lys, for which its FAA-Lys pool was in a severely short supply for milk protein synthesis in cows on both treatments (Table 10). Accordingly, extraction of PB-Lys amounted to 20.8 and $23.8 \%$ (different from zero, $P<0.01$ ) of the quantity extracted from the FAA pool of Lys in SFS- and DRSfed cows, respectively. However, whereas the quantities of His + PB-His extracted in SFS- and DRS-fed cows satisfied the need for milk protein synthesis, this was not the case regarding Lys, for which the quantities of FAA-Lys extracted and that degraded from PB-Lys in cows on both treatments still did not fully match the amounts excreted in milk. Additional sources for supplementing this shortage may be PB-Lys in peptides longer than those measured in the present experiment (3 kDa) or extraction from BC. Hanigan et al. (1991) reported that mammary arteriovenous differences of Lys in whole blood were approximately $50 \%$ higher than arteriovenous differences of plasma Lys. Because packed BC constitute between 24 and $30 \%$ of blood volume, this finding indicates that $\mathrm{BC}$ contain large quantities of Lys. In addition, Cant et al. (1993), while comparing the concentrations of FAA in plasma and whole blood, reported that except for a few cases of similar concentrations in both pools, the concentrations of most FAA in whole blood were lower than those in plasma. The few exceptions of essential FAA were Lys, His, and Leu, for which the concentrations in whole blood were higher than in plasma, indicating higher concentrations of these $\mathrm{AA}$ in $\mathrm{BC}$ than in plasma. In the present experiment, the extraction by the mammary gland of $\alpha$-AA-nitrogen from whole blood, as reported previously by Delgado-Elorduy et al. (2002a; Table 4), was $31.7 \%$ greater, 56.1 vs. $73.9 \mathrm{~g}$ of nitrogen/d $(P<0.01)$, in cows fed DRS and SFS, respectively. This difference is greater than the difference between treatments in total FAA + PBAA reported in the current paper (Table 10), which pointed at BC or longer peptides in whole blood as an additional source that was not covered by analyzing only the plasma pools. It also should be pointed that the quantities extracted considerably surpassed those excreted in milk.

However, the aforementioned point does not diminish the role of the PBAA pool as a reserve source. Indeed, in the current paper, extracted His (i.e., free His + PBHis combined) matched the amounts excreted in milk protein, and apparently, there was no need for BCstored His, implying that the PB-His reserve pool was used first. Extraction of Lys from the FAA pool fell short of the needs for milk protein synthesis, and despite its apparently large reserve in blood cells (Hanigan et al., 1991), a substantial proportion, in both treatments, was extracted from the PB-Lys pool, thus once again indicating the PBAA pool as the first reserve source used, and in the present case, as the major backup, for eliminating the shortage from the FAA pool.

\section{CONCLUSIONS}

The DMI of cows in midlactation fed diets based on $40 \%$ DM from SFS grain was slightly less for the whole experimental period as compared with cows fed DRS grain, but was considerably less in the last $3 \mathrm{~d}$, blood sampling day included. However, the SFS diets increased milk yield numerically by $4.5 \%$ and significantly increased AA secreted in the milk, per kilogram of DMI. This enhanced efficiency in milking performance was the result of a substantial increase in microbial protein synthesis in cows fed the SFS diets, as presented in a previous paper for this experiment. The PDV and liver and splanchnic fluxes were characterized by smaller FAA and larger PBAA fluxes in cows fed the SFS diets, which could be considered a dietary effect. Total PB-EAA in PDVF, expressed as a proportion of total free EAA, constituted 8.0 to $18.5 \%$, but individual PB-EAA content, as a proportion of individual free EAA, varied from 2 to $73 \%$, and these amounts substantially supplemented the shortages of AA from the FAA pool for either milk protein production or other metabolic functions. Total PB-EAA in MU, as a proportion of total free EAA, varied between 3.7 and $4.8 \%$, but the proportion of individual PB-EAA varied from 2.5 to $23.8 \%$. More studies are needed to substantiate the effect of diet on the extent and profile of PDVF of FAA and PBAA 
and the release from the latter of FAA to their pool in blood. Quantifying dietary effects on PDVF of FAA and PBAA, and the role of the latter as a reserve pool, may lead to improvements in diet formulations and in the efficiency of dietary protein utilization, and reduce environmental contamination arising from excess fed protein.

\section{ACKNOWLEDGMENTS}

The authors wish to thank the United States-Israeli Binational Agricultural Research and Development Fund (BARD, Beit-Dagan, Israel), and USDA-ARS (Beltsville, MD) for its partial financial support for this research project. Thanks are also extended to Hilary Voet, Department of Agricultural Economics, the Hebrew University of Jerusalem (Rehovot, Israel), for carrying out the statistical analyses and to Y. Aharoni, Department of Animal Sciences, the Volcani Institute (Neve-Yaar, Israel), for his useful comments.

\section{REFERENCES}

Al-Dehne, A., J. T. Huber, R. Wanderly, C. B. Theurer, M. Passaraki, and D. DeYong. 1997. Incorporation of recycled urea N into ruminal bacteria flowing to the small intestine of dairy cows fed a high grain or high forage diet. Anim. Feed Sci. Technol. 68:327-338.

Backwell, F. R. C., M. Hipolito-Reis, D. Wilson, L. A. Bruce, V. Buchan, and J. C. MacRae. 1997. Quantification of circulating peptides and assessment of peptide uptake across the gastrointestinal tract of sheep. J. Anim. Sci. 75:3315-3322.

Bar-Peled, U., Y. Aharoni, B. Robinson, I. Bruckental, R. Lehrer, E. Maltz, C. Kinight, J. Kali, Y. Folman, H. Voet, H. Gasitua, and H. Tagari. 1998. The effect of enhanced milk yield of dairy cows by frequent milking or suckling on intake and digestibility of the diet. J. Dairy Sci. 81:1420-1427.

Bauchop, T., and S. R. Elsden. 1969. The growth of microorganisms in relation to their energy supply. J. Gen. Microbiol. 23:457-469.

Bequette, B. J., F. R. C. Backwell, C. E. Kyle, A. G. Calder, V. Buchan, L. A. Crompton, J. France, and J. C. MacRae. 1999. Vascular sources of phenylalanine, tyrosine, lysine, and methionine for casein synthesis in lactating goats. J. Dairy Sci. 82:362-377.

Bidlingmeyer, B. A., S. A. Cohen, and T. L. Tarvin. 1984. Rapid analysis of amino acids using pre-column derivatization. J. Chromatogr. 336:93-104.

Brockman, R. P., and E. N. Bergman. 1975. Quantitative aspects of insulin secretion and its hepatic and renal removal in sheep. Am. J. Physiol. 229:1338-1343.

Bruckental, I., I. Ascarelli, B. Yosif, and E. Alumot. 1991. Effect of duodenal proline infusion on milk production and composition in dairy cows. Anim. Prod. 53:299-303.

Cant, J. P., E. J. DePeters, and R. L. Baldwin. 1993. Mammary amino acid utilization in dairy cows fed fat and its relationship to milk protein depression. J. Dairy Sci. 76:762-774.

Chen, H., E. A. Wong, and K. E. Webb Jr. 1999. Tissue distribution of a peptide transporter mRNA in sheep, dairy cows, pigs, and chickens. J. Anim. Sci. 77:1277-1283.

Czerkawski, J. W. 1976. Chemical composition of microbial material in the rumen. J. Sci. Food Agric. 27:621-632.

Delgado-Elorduy, A., C. B. Theurer, J. T. Huber, A. Alio, O. Lozano, M. Sadik, P. Cuneo, H. D. De Young, J. Simas, J. E. P. Santos, L. Nussio, C. Nussio, K. E. Webb Jr., and H. Tagari. 2002a. Splanchnic and mammary nitrogen metabolism by dairy cows fed dry-rolled or steam-flaked sorghum grain. J. Dairy Sci. 85:148159.
Delgado-Elorduy, A., C. B. Theurer, J. T. Huber, A. Alio, O. Lozano, M. Sadik, P. Cuneo, D. DeYoung, J. Simas, J. E. P. Santos, L. Nussio, C. Nussio, K. E. Webb Jr., and H. Tagari. 2002b. Splanchnic and mammary nitrogen metabolism by dairy cows fed steamrolled or steam-flaked corn. J. Dairy Sci. 85:160-168.

Elwyn, D. H., W. J. Launder, H. C. Parikh, and E. M. Wise Jr. 1972. Roles of plasma and erythrocytes in interorgan transport of amino acids in dogs. J. Physiol. 222:1333-1342.

Haibel, G. K., L. A. Guilbault, P. Villeneuve, and W. W. Thatcher. 1989. Aortic catheterization in cattle via the costoabdominal artery and validation for progesterone and estradiol-17 sample collection. Am. J. Vet. Res. 50:1923-1925.

Hanigan, M. D., C. C. Calvert, E. J. DePeters, B. L. Reis, and R. L. Baldwin. 1991. Whole blood and plasma amino acid uptakes by lactating bovine mammary glands. J. Dairy Sci. 74:2484-2490.

Huntington, G. B., C. K. Reynolds, and B. H. Stroud. 1989. Techniques for measuring blood flow in splanchnic tissues of cattle. J. Dairy Sci. 2:1583-1595.

Jorgenson, G. N., and B. L. Larsen. 1968. Conversion of phenyalanine to tyrosine in the bovine mammary secretory cell. Biochim. Biophys. Acta 165:121-126.

Katz, M. L., and E. N. Bergman. 1969. Hepatic and portal metabolism of glucose, free fatty acids, and ketone bodies in the sheep. Am. J. Physiol. 216:953-960.

Koeln, L. L., T. G. Schlaghack, and K. E. Webb Jr. 1993. Amino acid flux across the gastrointestinal tract and liver of calves. J. Dairy Sci. 76:2275-2285.

Lapierre, J., F. Bernier, P. Dubreuil, C. K. Reynolds, C. Farmer, D. R. Ouellet, and G. E. Lobley. 2000. The effect of feed intake level on splanchnic metabolism in growing beef steers. J. Anim. Sci. 78:1084-1099.

Mabjeesh, S. J., O. Gal-Garber, J. Milgram, Y. Feuermann, M. CohenZinder, and A. Shamay. 2005. Aminopeptidase N gene expression and abundance in caprine mammary gland is influenced by circulating plasma peptide. J. Dairy Sci. 88:2055-2064.

Mepham, T. B. 1982. Amino acid utilization by lactating mammary gland. J. Dairy Sci. 65:287.

NRC. 1989. Nutrient Requirements of Dairy Cattle. 6th rev. ed. Natl. Acad. Sci., Washington, DC.

Oliveira, J. S., J. T. Huber, J. M. Simas, C. B. Theurer, and R. S. Swingle. 1995. Effect of sorghum grain processing on site and extent of digestion of starch in lactating dairy cows. J. Dairy Sci. 78:1318-1327.

Remond, D., L. Bernard, and C. Poncet. 2000. Free and peptide amino acid net flux across the rumen and the mesenteric- and portaldrained viscera of sheep. J. Anim. Sci. 78:1960-1972.

Roets, E., R. Verbeke, G. Peeters, A. Axmann, and G. Proksch. 1979. Metabolism of ornithine in perfused goat udder. J. Dairy Sci. 62:259-269

Santos, F. A. P., J. T. Huber, C. B. Theurer, R. S. Swingle, and J. M. Simas. 1997a. Response of lactating dairy cows to various densities of sorghum grain. J. Anim. Sci. 75:1681-1685

Santos, F. A. P., J. T. Huber, C. B. Theurer, R. S. Swingle, Z. Wu, J. M. Simas, K. H. Chen, S. C. Chen, J. Santos, and E. J. DePeters. 1997b. Comparison of barley and sorghum grain processed at different densities for lactating dairy cows. J. Dairy Sci. 80:2098-2103.

Seal, C., and D. S. Parker. 1996. Effect of intraruminal propionic acid infusion of mesenteric- and portal-drained viscera in growing steers fed forage diets. II. Ammonia, urea, amino acids, and peptides. J. Anim. Sci. 74:245-256.

Shabi, Z., I. Bruckental, S. Zamwell, H. Tagari, and A. Arieli. 1999. Effect of extrusion of grain and feeding frequency on rumen fermentation, nutrient digestibility, and milk yield and composition in dairy cows. J. Dairy Sci. 82:1252-1260.

Sniffen, C. J., and P. H. Robinson. 1987. Microbial growth and flow as influenced by dietary manipulation. J. Dairy Sci. 70:425-441.

Tagari, H., A. Arieli, S. Mabjeesh, I. Bruckental, S. Zamwell, and Y. Aharoni. 1995. Assessment of duodenal amino acid profile in dairy cows by the in situ method. Livest. Prod. Sci. 42:13-22.

Tagari, H., K. Webb Jr., B. Theurer, T. Huber, D. DeYoung, P. Cuneo, J. E. P. Santos, J. Simas, M. Sadik, A. Alio, O. Lozano, A. Delgado- 
Elorduy, L. Nussio, C. Nussio, and F. Santos. 2004. Portal drained visceral flux, hepatic metabolism, and mammary uptake of free and peptide-bound amino acids and milk amino acid output in dairy cows fed diets containing corn grain steam flaked at 360 or 490 g/L. J. Dairy Sci. 87:413-430.

Theurer, C. B., J. T. Huber, A. Delgado-Elorduy, and R. Wanderly. 1999. Invited review: Summary of steam-flaking corn or sorghum grain for lactating dairy cows. J. Dairy Sci. 82:1950-1959.

Thorlacius, S. O., A. Dobson, and A. F. Sellers. 1971. Effect of carbon dioxside on urea diffusion through bovine ruminal epithelium. Am. J. Physiol. 220:162-170.
Vanhatalo, A., P. Huhtanaen, V. Toivonen, and T. Varviko. 1999. Response of dairy cows fed grass silage diets on abomasal infusions of histidine alone or in combinations with methionine and lysine. J. Dairy Sci. 82:2674-2685.

Verbeke, R., S. Simeonov, and G. Peeters. 1967. Incorporation de la L-methionine- ${ }^{35} \mathrm{~S}$ dans la caseine par la glande mammaire isolee brebis. Arch. Int. Physiol. Biochem. 75:658-666.

Wholt, J. E., J. H. Clark, R. G. Derring, and C. L. Davis. 1977. Valine, leucine and isoleucine metabolism by lactating bovine mammary tissue. J. Dairy Sci. 60:1875-1882. 